\title{
Willpower of Retentive Factors in Job Level and Recital Human Resource Management in Project
}

\author{
YuSheng Kong \\ Professor, Dean in the School of Finance and Economics, Jiangsu University, Zhenjiang \\ 212013, People's Republic of China \\ Rabnawaz Khan (Corresponding Author) \\ $\mathrm{PhD}$ Scholar in the School of Finance and Economics, Jiangsu University, Zhenjiang \\ 212013, People's Republic of China, \\ E-mail: khan.rab@yahoo.com \\ Mohammad Imran \\ PhD Scholar in the School of Finance and Economics, Jiangsu University, Zhenjiang \\ 212013, People's Republic of China
}

Received: November 21, 2017 Accepted: December 19, 2017 Published: March 5, 2018

doi:10.5296/ijld.v8i1.12173 URL: https://doi.org/10.5296/ijld.v8i1.12173

\begin{abstract}
This research will focus on the "Willpower Of Retentive Factors In Job Level And Recital Human Resource Management In Project", it's based differences in project human resource management as an application of the John Bauknecht (2008) study "Embattled Worker Retention: Performance-Based and Job-R elated Differences in Reported Reasons for Staying" in the various production and engineering industrial projects of southern Punjab considering Project Human Resource Management as a fundamental basic function of project administration.

This study has its importance in life of a student from different aspects. As for as this study is part of students degree award. It helps students to gain a practical knowledge of the organization and compare it with the theoretical knowledge gained during the four years course of study. Personally this study helped me recognize my abilities and suitability to work in industrial sector of Punjab.
\end{abstract}

Keywords: Job performance, job retention factors 


\section{Introduction and Overview}

In Punjab industries employment is considerable formal and desirable sufficient value of organization wealth. Researcher have could be found to fill them in the previous result of worker performance by ranking as well. Moreover, once employed, workers would often employ their entire careers in those jobs.

Correspondingly workers were loyal to their establishments and continued often on the job until their withdrawal. As a result of this, proprietors were loyal to their teams by taking care of them in a more authoritarian way. Grippingly, while today's organizations are indeed changed, the challenge of retention is growing. Industrial workers retention factors refers to an organization's efforts to keep in employment those workers of whom the organization has a positive evaluation in industries, who would generally only leave the organization through voluntary letter of resignation (Mangel 2001). Thus, employers need to retain their high recitalists who have acquaintance and skills that are critical for the organization to maintain a competitive improvement.

Netswera et al. (2005) suggest that retention factors encouragement the revenue intentions of workforces (i.e. their intent to leave the organization) and should be well-thought-out in the design of retention strategies. While the reputation of worker retention to organizational effectiveness and proficiency is clear, there is currently no single framework that guides examination and run-through (Cerdy \& Langnick-Hall 2011).

Unrelatedly of which imaginary model is well-thought-out, there are situations in which voluntary worker turnover may be unavoidable and beyond the control of supervision (Dalton, Todor \& Krackhardt 1982). Subsequently, the focus of this study was on factors that administration can rheostat and that may influence workers to outing with the organization. The purpose of Project Human Resource Management is to ensure that the project has sufficient human resources sectors in Punjab, with the correct skill sets and experience, for the project to be efficaciously completed. It not only aimed at induction of the skilled and right human resource for the Project but also word of retention of these hominoid resource for the effective maintenance of the projects also comes under Project Human Resource Administration.

\subsection{Significance of Study}

The significance of this study was to inaugurate that operative retention has a momentous role on job presentation. Thus, there is the requirement to afford career psychotherapy, drill, career advancement and progress for workers in the Brewery Industry. Additionally, the study generates concentration from the wider standpoint of worker preservation and is of actual interest to person's disturbed Punjab industries with job presentation in Accra Brewery Partial. The findings of this study will help to provide a foundational basis for the work in the area of unindustrialized competitive pay and reimbursements package for the workforces of Accra Brewery Ghana Limited. ( unindustrialized retention approaches that will have positive effect on job presentation )he study will help employers to contrivance programs such as flexible waged appointments and administrator exercise initial to reduce professional attitude in 
Punjab industries.

\subsection{Job Performance and Levels Effects}

In the context of the present study, job characteristics refer to the helpful aspects of the job. Job appearances may include varied work, openings to solve inspiring problems, openings to work with the best people, independence, flexibility and being able to pursue thought-provoking projects (Dackel, 2003). Job appearances that lead to feelings of increased competence and relevance of work were found to increase the maintenance of workers (Döckel, 2003).

Providing workers with sufficient training by retention factors and their opportunities should be viewed as an essential speculation strategy for worker growth and enlargement (Daekel, 2003; Kraimer). This practice constitutes an important part of the organization's accomplishment of the unceremonious contract between itself and workers, which deepens workers' sense of attachment to the organization (Bergiel et al., 2009). With the job embeddedness construct, training and enlargement occasions should improve the fit between the underling and the job, as well as characterize a sacrifice that must be knowledgeable if the worker chooses to take assignation elsewhere (Machall et al., 2001).

According to Ostaraker (2002), the worker retention factors and their satisfaction level for the worker's in industries are considered the Cornerstone for success of industries. Past study divided it into social, rational or physical Width. The syndicate is based on social contacts at works, entrances of the work task or the physical and material surroundings associated with work. The withholding factors of the mental dimension are work physiognomies, workers are retaining by flexible tasks where they can use their knowledge and see the results of their efforts. The social measurement refers to the contact workforces have with other people, both center and peripheral.

The physical dimension consists of working environments and pay Van Kappenberg (2000), recommended that worker become more loyal and stay in the organization when they identify themselves within a group and underwrite to the performance as a group. This submission relies on work performed by Locke and the goal background theory he developed. The goal is team presentation and the individual feeling part of the group. The focus of Locke was on the goal, but in order to reach the goal one must assistant oneself with the group and commission. Glen (2006), describes another background manager can use when collaborative with its workers to know that the cause of retention consist of nine different predictors; executive processes, role challenge, values, work, life balance, information, stake/leverage/acknowledgement, administration, work environment and product or service.

According to Fitznes (2000) predictable that only one factor is not accountable in administration of worker's preservation, but there is numerous factors predisposed in worker's maintenance which need to manage harmoniously i.e. compensation \& rewards, job security, training \& developments, supervisor support culture, work environment and suggestion justice etc. Consequently, association utilizes extensive range of human resource management factors influence in worker assurance and maintenance (Stein, 2000; Beck, 2001; 


\section{Macrothink}

Clarke, 2001; in worker retention the Parker and Wright, 2001). This study also have unprejudiced to find out the factors which is more influence in workforces retention, for this purpose these factors are categorized into legislative factor i.e. supervisor support, managerial justice, organization image and work environment and Human resource factors i.e. worker value match, training \& enlargement, remuneration \& reward, job security and workers advancement aspect.

\subsection{Statement of the Problem}

The fast-paced industrial changes that have transpired, and will remain to occur, in the marketable atmosphere have also surfaced in the retention factors municipal.

\subsubsection{Performance Problems}

- Job level performance and their duties are affected by the time necessary to deal with the attitude problem of industrial management skills.

- Routine improvement negotiations become unsatisfying urgings and debates

- Spell spent with the arrogance problems takes administrators away from workforces who want to improve

- Executive's enthusiasm is moderated after working with this badly-behaved worker

- Uncertainty not addressed, the attitude can become transmissible and infect an complete industrial department

- Individuals are reluctant to discourse the problem because of this person's quarrelsome countryside of entire industries of Punjab.

- Efficiency is exaggerated because other workers refuse to work with this arrogance badly-behaved industries of Punjab.

- Individuals walk on "coverings" around this underling afraid they will blow up if slighted

- This insolence problem is causing other personnel to call in sick, application a allocation or quit of worker performance by level of rank.

- Regulars, customers or other administrators request this person not slog with their people

- Supervisors have not received supervision skills retention factors or hominoid resources retention factors

\subsubsection{Retention Factors Deliverables}

- Recover worker presentation and morale by plummeting workplace conflict

- Intensification supervisory consistency and usefulness in handling attitude difficulties

- Improve efficiency and efficiency by determining attitude problems 


\section{Macrothink}

International Journal of Learning and Development

ISSN 2164-4063 2018, Vol. 8, No. 1

- Create more communication and collaboration between workforces

- Thwart emotionally emotional situations from becoming unsatisfying, energy strenuous urgings

- Increase self-assurance and comfort level of supervisors in dealing with difficult workforces

- Distinguish and apprehend the most communal causes of attitude complications

- Advance assertive rejoinder plans for difficult types of people and dispositions

- Regulate when it is safe to begin the formal chastisement process and how to safely document "bad arrogance" Deal with workers who deny difficulties and try to blame everybody else

- Prevent attitude complications by creating a encouraging work temperature.

- Generate effective routine and behavior turn-around strategies

- Be nonaggressive and smart when haughtiness problems may stem from aggravation, outmoded or age variations

- Positive government retention factors to conversion insolence.

\subsection{Retention Factors and Development Objectives}

There has been much work done in the past aimed at determining the explanations resulting in workforces to quit their jobs or change officialdoms (e.g., Griffeth, Hom, \& Gaertner, 2000), nevertheless, very little is notorious so far approximately the variables encouraging the workers to stay with their institute.

In this study, we will not only define the factors encouraging employee maintenance but also observe employees at different job levels and performance, and examine how these retention factors differ for high performers and those at different levels of the association within any development (Griffeth \& Hom, 2001) The principal objective of retention factors and development division in department is to make sure the availability of a skilled and willing workforce to an industrial organization Punjab. In addition to that, there are four other objectives of Individual, Organizational, Functional, and Societal.

Individual objectives - Help workers in achieving their personal goals, which in turn, enhances the individual contribution to an organization.

Organizational objectives - Assist the organization with its primary objective by bringing individual effectiveness.

Functional objectives - Maintain the department's contribution at a level suitable to the organization's needs.

Societal objectives - Ensure that an organization is ethically and socially responsible to the needs and challenges of the society. 


\subsection{Scope of Study}

This study emphasis in the following scope:

- To basically identify the employees retention factors with 12 different level of satisfaction on industrial sectors job.

- This study is accommodating to that pure industrial environment for proper research.

- It is helpful to identify the employer's level of retention factors by job level and upward and downward strategies.

- This study is helpful to the association for categorizing the area of disappointment of job of the workforces.

- This study services to variety a executive pronouncement to the establishment.

\section{Literature Review}

Retention factors in job level also has a significant effect on worker presentation. Firms can develop and enhance the quality of the current workers by providing all-inclusive exercise and expansion. Indeed, research indicates that savings in retention factors in problem-solving, teamwork and relational relations result in beneficial firm level conclusions (Russell, Terberg, \& Powers, 1985; Bartel, 1994; Cianni \& Wnuck, 1997; Ettington, 1997; Barak, Maymon, \& Harel, 1999). In a rare organization level study, Russel et al., (1985) found that retention factors was interrelated with sales volume per underling and store image in a sample of retail outlet supplies.

In the retaining factors, and level of related job performance directly effects companies performance with 12 or more retention factors, sometime it created big flaws between performance and job level. Firms can develop and enhance the quality of the current personnel by providing all-inclusive retention factors and expansion by different retention factors. Research indicates that performance and different job level in problem-solving, decision-making, teamwork, and interpersonal families result in advantageous firm level conclusions (Russell, Terberg, \& Powers, 1985; Bartel, 1995; Cianni \& Wnuck, 1998; Ettington, 1998; Barak, Maymon, \& Harel, 1999).

Effective retention factors programs are organized and continuous. In other words, retention factors must be viewed as long term process, not just an infrequent and or slapdash events of different industrial environments. By this industrial organizations make massive effective force on the workers and created the system for the workers. With high retention factors which is promote the skills and mentally retraction to the workers. High performers will cite retention factors that indicate low desirability of movement (i.e., advancement opportunities, constituent attachments, extrinsic rewards, flexible work arrangements, job satisfaction, location, non-work influences, organizational commitment, organizational justice, and organizational prestige) at a higher rate than low performers. Low performers will cite factors that reflect low ease of movement (i.e., investments, lack of alternatives) at a higher rate than high performers and to sustain them in the organization. In today's industrial sectors 
investment situation only high salary and description is not significant for workers to retain them in the organization, but others factors also play imperative role in their retention. The intent of this research is to how the administrations retain the talented workers in the association focusing on the factors i.e. career development, leave policy, management style, work environment, remuneration \& rewards, Organization Justice, and performance appraisal, and this research also helpful to know the determent that why workers leave the organization.

The successful and prosperous future of an organization is dependent on its skilled, knowledgeable culture and worker satisfaction with different level of job and ranking. That is why retention factors is a fundamental and effectual and instrument in successful accomplishment of the Punjab industries goals and ideas. Retention factors of worker not only improve them resourcefully, but also gives them resourcefully, but also gives them a chance to learn their job virtually and perform it more competently hence increasing Punjab industries' productivity. Retention factors design refers to the degree to which the retention factors has been designed and delivered in such a way that provides trainees the ability to transfer learning back to the job (Halton, 2000).

By the observed that exploration directed at building an exigency model of transfer-oriented retention factors intervention design would provide information important for developing retention factors atmospheres more conducive to encouraging transfer in terms of efficiency usefulness. Identification of retention factors needs, design and implementation of retention factors programmer, transmission of training, and evaluation of programmer benefits are key activities (Krishnaveni \& Sripirabaa, 2008) in addition to studying wide-ranging retention factors variables such as types of training, selection of beginners, selection criteria, evaluation appliances etc.

The relationship between skill acquisition and job satisfaction is not forthright. First, there is the distinction between general and detailed skills. The portability of general skills may raise job satisfaction as it is easier to move to other jobs where consummation is higher. In contrast, specific skills bind the worker to the Punjab industries and may reduce consummation by creating a barrier to exit as workers will lose a portion of the return on such skills if they move. The same authors (1999) found that over-educated graduates had significantly lower job satisfaction than those who were in graduate-level jobs by different retention factors.

In one of the new studies to focus on skilling Allen and van der Velden (2001) differentiated between education and skill mismatches, finding only a weak relationship between the two. Importantly, they found a significant negative relationship between skill mismatch and job satisfaction, while the link between educations mismatch and job satisfaction was insignificant. Bauer (2004), using the European Survey on Working Conditions covering all EU member states, found that involvement of workers in High Performance Work Organisations (HPWOs) (Note 1) was associated with higher job satisfaction. Further, a skill index, derived from information on the number of days of retention factors paid for or provided by the employer had, with the UK being an exception, a positive and significant effect on the 15 countries overall. (Note 2)

Retention factors may influence workplace workers performance directly by raising output 
per worker or be measured tortuously through its impact on the wage on the postulation that this is equal to the marginal productivity of labor.

However, this will not be the case if there are imperfections in the product or labor marketplaces. Dearden et al. (2006) were able to measure the impact on efficiency directly using a panel of British industries over the period 1984 to 1997.

They found that a one percentage point increase in retention factors was associated with an increase in value added per hour of about 0.6 per cent, but an increase in wages of only 0.3 per cent consistent with employer monopoly power in the labor market, so that using wages as a proxy for productivity of worker's productivity.

However, correlation does not always imply causation and most of the studies cited by Locke used simple univariate analysis and do not undertake more sophisticated multivariate analysis. In one of the seminal papers on job satisfaction, Freeman (1978) was one of the first economists to analyzed the connection between quits and job satisfaction. Based on panel data from two different US sources, the National Longitudinal Survey (NLS, 1966-1971) and the Michigan

\section{Methodology}

In the research data were conducting by questionaries' expected designed which is already distributed in four parameter with two hypothesis. During research it with help of different advisor and representative interviewers, different interviewers have respond different point and discuss the basic experience in different organization fields. The main objective of research is to find out the truth which is hidden and which has not yet been known in job performance and their effects according to job performance and their different level in jobs. Although each research study has its own specific purpose, research objectives may be considered to be falling into the following categories:

- In case of exploratory research conducting data as for new insights and achieving targets with level of jobs and their performance.

- In second step, with help of interviewers test hypothesis of causal relationship between/among descripted synopsis, especially level in job variables of different companies.

- In third step conduct data with portray of organization accurately the characteristics of a particular situation, individual or a group of members.

\subsection{Methods and Technique}

In Research method researcher refers to all those methods/techniques that were used for conducting a research with different tools and scales. Research methods or techniques thus refer to the methods and tools the researchers use in performing research operations according to descripted scale and nature of questions.

These methods and techniques fall in categories: 


\section{Macrothink Institute ${ }^{T M}$}

- Researcher methods used for selection of samples and collection of data from representative interviewers from the different areas of Punjab.

- Researcher have distributed the questions area according the research framework.

- Researcher used statistical techniques and scale of analysis used for establishing relationships among the relevant variables.

- Researcher used for evaluating the accurateness of the results obtained by significant figures and facts.

\subsection{Developing Working Hypothesis During Conducting Research}

In the research the basic role of hypothesis to determine the basic view of research and track. It indicate the facts of finding and analysis in environment according to research questions.

Hypothesis 1: High performers will cite retention factors that indicate low desirability of movement (i.e., advancement opportunities, constituent attachments, extrinsic rewards, flexible work arrangements, job satisfaction, location, non-work influences, organizational commitment, organizational justice, and organizational prestige) at a higher rate than low performers. Low performers will cite factors that reflect low ease of movement (i.e., investments, lack of alternatives) at a higher rate than high performers

Hypothesis 2: Hourly employees are expected to cite transactional retention factors (i.e., extrinsic rewards, flexible work arrangements) at a higher rate than managerial and professional employees. Managerial and professional employees are expected to cite relational factors (i.e., advancement opportunities, constituent attachments, job satisfaction, organizational commitment, organizational justice, and organizational prestige) at a higher rate than hourly employees.

\subsection{Preparing the Research Design}

The research was designed in two groups and then each group have distributed in two sub groups. In which each sub group have ten and two different parameters. Like in job performance reliability factor with high and low and then in high performance advancement opportunities, constituent attachments, extrinsic rewards, flexible work arrangements, job satisfaction, location, non-work influences, organizational commitment, organizational justice, organizational prestige effects. Also in low performance investments, lack of alternatives) at a higher rate than high performers.

Same as like that in job level the sub groups have distributed ten and two sub parameters. Likes in advancement opportunities, constituent attachments, job satisfaction, organizational commitment, organizational justice, and organizational prestige, and extrinsic rewards, flexible work arrangements factors of high and low job level. 


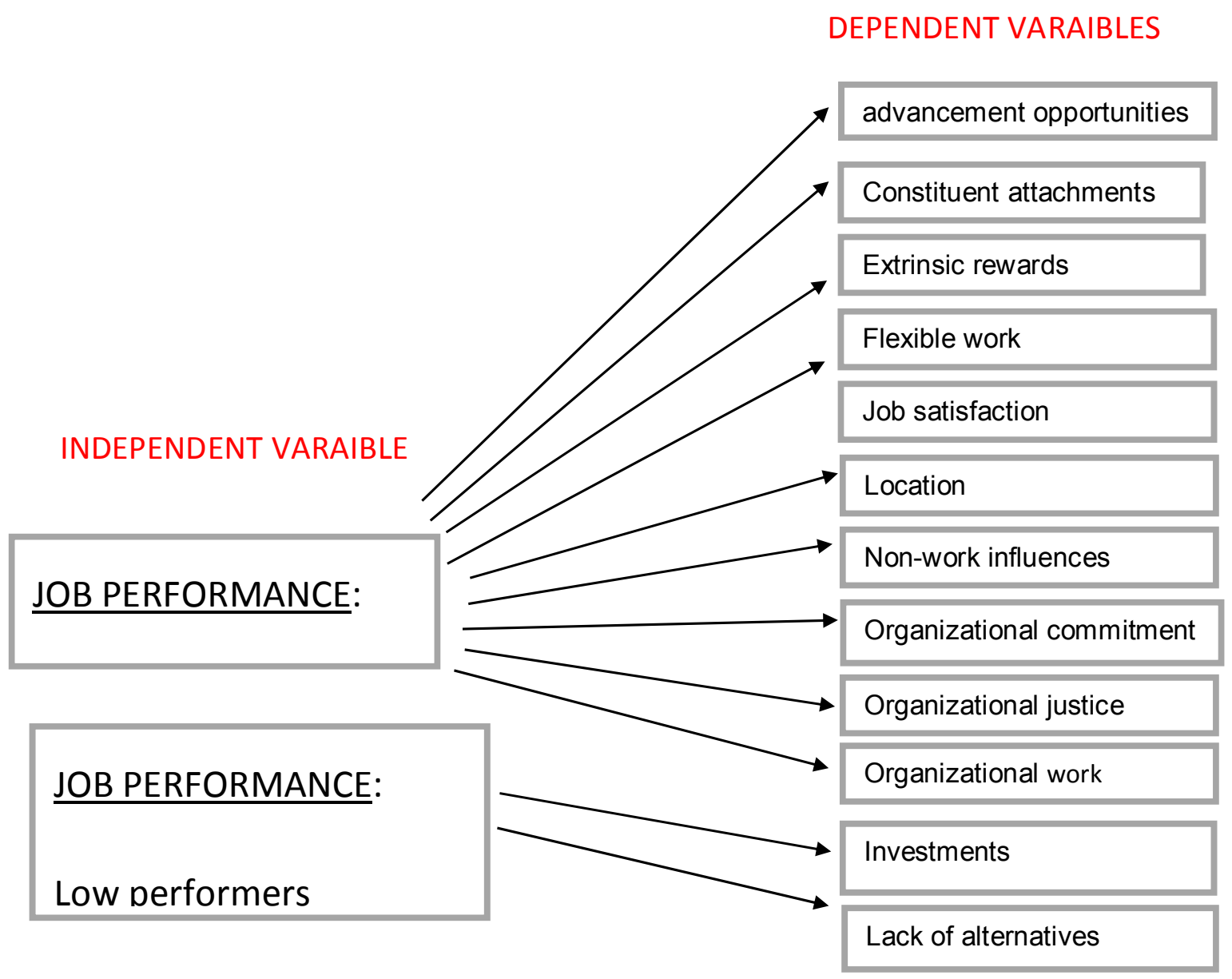




\section{DEPENDENT VARAIBLES}

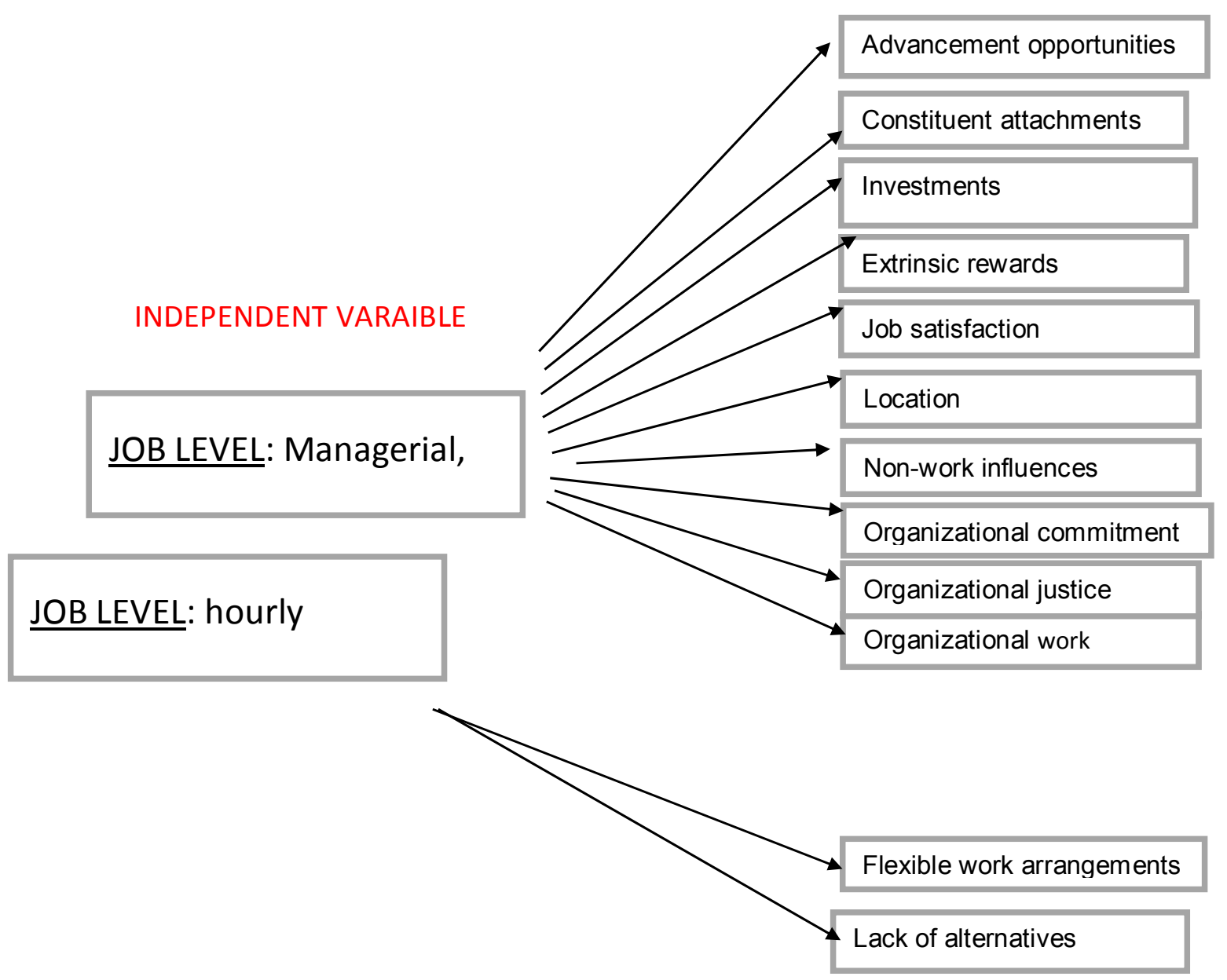

\subsection{Data Sources}

In the research, the study of data was distributed questionnaire in 12 statement of job level of performance and 12 retention factors of job level high and low performance. In addition to demographic view taking information about the field as well. According to research design data taking from the industrial area of southern Punjab. The study have also determine the following

- Southern area of industries

- Northern area of industries

- Small industries and joint enterprises

\subsection{Data Collection Techniques}

In the research questionnaire were formulated as a data collection tool by different parameter of job performance and job level. In addition to demographic information taking from the corporate sectors as well, dependent and independent variable in two groups of research. There was following steps below 


\section{Macrothink}

- Distribute the groups of industries along with parameters

- Industries were selected according to job performance and level of job

- Distribute the industrial department according to advancement opportunities, constituent attachments, extrinsic rewards, flexible work arrangements, job satisfaction, location, non-work influences, organizational commitment, organizational justice, and organizational prestige effects.

- Same as above distribute the criteria of research lack of performance.

\subsection{Sampling techniques}

Sample Size: Minimum sample size will be 1000, including employees irrespective of age or gender, working with different industrial different departments in research period of 2013-14 and alos conducted data from small enterprise additionally for variability factors of dependent variables.

\subsection{Data Analysis and Interpretation}

In the data analysis result will be compiled by using SPSS and frequency counting by excel as well. The results will be assessed by statically test and analyzed by applying Analysis of Variance (ANOVA) with liner and quadratic. Analysis will be proceed by Cronbach alpha reliability test of job performance and then job level and their effects. Then directly will find out the actual frequency level of each question in job performance and their sub component. At the end of each parameter individually check the reliability and then by coss-tab frequency distribution calculate the chi-square individually along with job level each parameter.

However, with individually ANOVA both result will define the actual reliability consistency of job performance with 12 retention factors and 12 statement factors of level of performance, also individually interpretation of sum of square of each test in within and in-between groups.

\subsection{Ethical Considerations}

1. Basically to find out the job performance level with different intention factors.

2. Departmentalization procedure and effects their job performance level.

3. Impact of high job performance as level low job performance

4. Ranking of level also determine with different scale of productivity of firm.

5. Comprehensive organization change in policies and rule regulation.

6. Effects of managerial structure and their performance.

\subsection{Questionnaires}

According to framework researcher have designed questionnaires.

1. I love the job and I have lots of fun;

2. I believe the pay, benefits, and bonus incentives are competitive compared to other 


\section{Macrothink}

companies

3. The people I work with are like family to me

4. I believe in loyalty to the company that hired me

5. I believe in loyalty to the company that hired me

6. Company is highly respected; the rest of the town usually follows what my company does

7. I can't find another job; I received no other job offers while looking for work

8. have been here for so long, I don't want to start over; I have many years invested

9. This company offers me the chance to move up; I see the potential and I see a future here;

10. The company cares what its' employees think and lets us give input / I am satisfied with the company policy and procedures

11. I like the flexible work hours

12. I stay employed here because I want a better life for my child/My schedule allows a very nice home life

\section{Finding and Analysis}

In the last step of formulating the research design of job performance and job level specification have distributed in two parameter according to above hypothesis, I have discussed how I will analyze the data which is obtained from the filled questionnaire by respondents in different area. After the data are collected through questionnaire from the different area, I have assigned codes to each answer which is determining through respondents responses. Relationship between job performance and job level is analyzed by chi-square techniques along with cross tab relation among job performance and questionnaires. To check the data reliability and validity SPSS software will be used and to find out relationship correlation \& cross tabulation test will be run. 


\subsection{Cronbach's Alpha Reliability Statistics}

Table 1. Case processing of Cronbach's Alpha

\begin{tabular}{llll}
\hline Case Processing Summary & & \\
\hline & & $\mathrm{N}$ & $\%$ \\
\hline Cases & Valid & 1000 & 100.0 \\
& Excluded $^{\mathrm{a}}$ & 0 & .0 \\
& Total & 1000 & 100.0 \\
\hline
\end{tabular}

a. Listwise deletion based on all variables in the procedure.

Table 2. Reliability statistics

\begin{tabular}{ll}
\hline Reliability Statistics & \\
\hline Cronbach's Alpha & N of Items \\
\hline .822 & 10 \\
\hline
\end{tabular}

The overall Cronbach alpha is 0.822 which is reliability coefficient considered acceptable and represents the degree of internal consistency among a set questionnaire item. The item - total statistics table represents that the Cronbach alpha if the 1st question deleted it will drop the overall Cronbach alpha .744 with the removal of lack of alternatives and investment questions like in low performance and it will increase the overall reliability of the questionnaire, however it increases the Cronbach alpha value from .744 to .822. This is $7.8 \%$ increase as comparatively form the normal record of Cronbach's alpha. According to hypothesis the result have been distributed in two parameters. In first step the high performance High performers will cite retention factors that indicate low desirability of movement (i.e., advancement opportunities, constituent attachments, extrinsic rewards, flexible work arrangements, job satisfaction, location, non-work influences, organizational commitment, organizational justice, and organizational prestige) at a higher rate than low performers. Low performers will cite factors that reflect low ease of movement (i.e., investments, lack of alternatives) at a higher rate than high performers. 
4.2 Job Satisfaction

Table 3. Ranking of job satisfaction

\begin{tabular}{|c|c|c|c|c|c|c|c|}
\hline \multirow[t]{2}{*}{ Cross tab Q1 } & \multicolumn{6}{|c|}{ Ranking of Job satisfaction } & \multirow[b]{2}{*}{ Total } \\
\hline & Remarks & Outstanding & $\begin{array}{l}\text { High } \\
\text { successful }\end{array}$ & Successful & Marginal & $\begin{array}{l}\text { Need } \\
\text { Improvement }\end{array}$ & \\
\hline \multirow{6}{*}{ Job-Satisfaction } & No & 76 & 83 & 73 & 66 & 72 & 370 \\
\hline & & $20.5 \%$ & $22.4 \%$ & $19.7 \%$ & $17.8 \%$ & $19.5 \%$ & $100.0 \%$ \\
\hline & & 137 & 125 & 117 & 125 & 126 & 630 \\
\hline & & $21.7 \%$ & $19.8 \%$ & $18.6 \%$ & $19.8 \%$ & $20.0 \%$ & $100.0 \%$ \\
\hline & Total & 213 & 208 & 190 & 191 & 198 & 1000 \\
\hline & & $21.3 \%$ & $20.8 \%$ & $19.0 \%$ & $19.1 \%$ & $19.8 \%$ & $100.0 \%$ \\
\hline
\end{tabular}

In the job satisfaction the question have shown the outstanding result $20.5 \%$ out of 370 participants individually. $22.4 \%$ in high successful with 83 , which is more than $2.4 \%$ as comparatively outstanding results. However the result shows the high successful rate in case of "No" and in case of "Yes" 137 outstanding participant have accepted the level of performance with all depended variable but in same as above in high successful is 125 , its $3.7 \%$ as comparatively outstanding. This is more than 3\% in high successful. In marginal and need improvement $1.2 \%$ in case of "Yes" and $1.7 \%$ more than from marginal to need improvement. The retention of high performance based advancement opportunities, constituent attachments, extrinsic rewards, flexible work arrangements, job satisfaction, location, non-work influences, organizational commitment, organizational justice, and organizational prestige in dependent variables from which job satisfaction is 61out of 1000 , and $21.7 \%$ out of 630 participants. Therefore the result shows the high performance dependent variable of job satisfaction. 


\section{Al Macrothink}

International Journal of Learning and Development

ISSN 2164-4063 2018, Vol. 8, No. 1

\subsubsection{Graphical Justification}

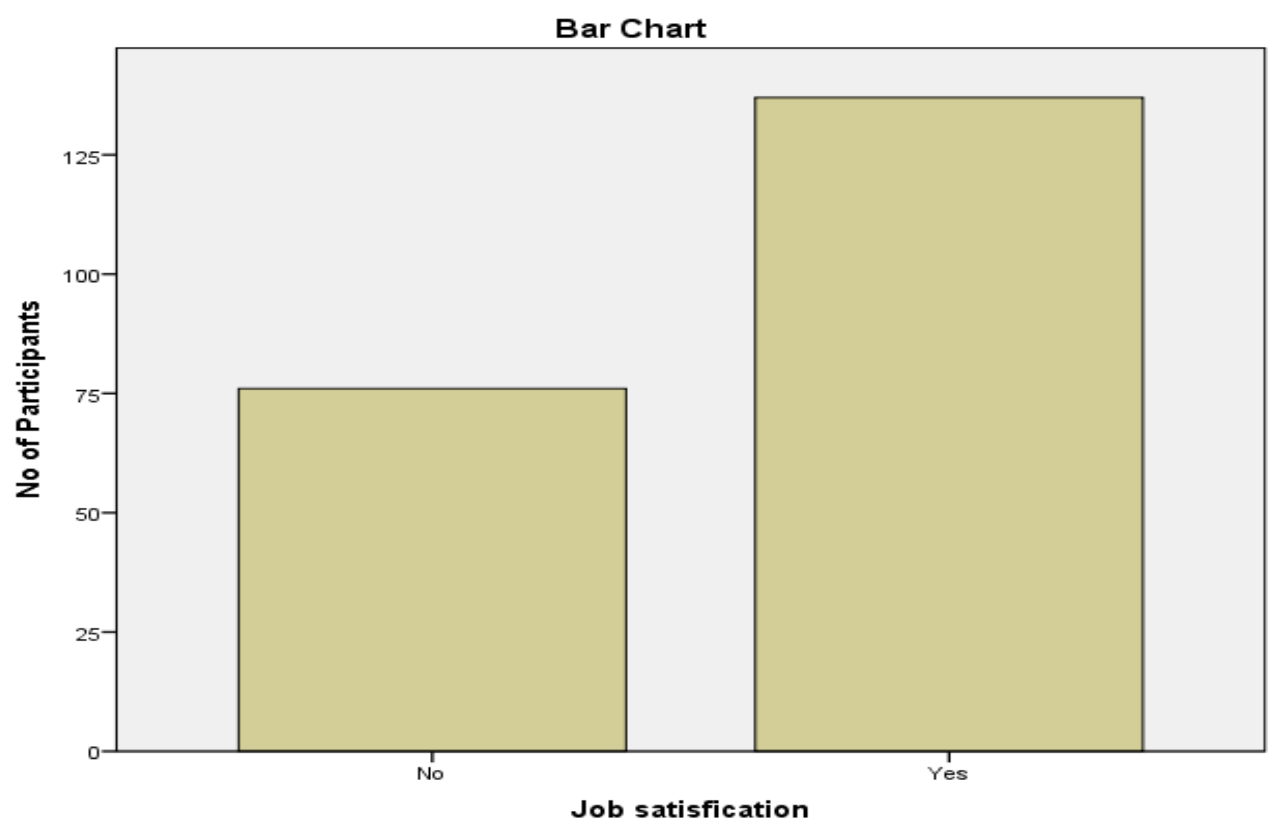

Figure 1. Bar graph of job satisfaction

In the bar chart the number of participants variation is 75 to 132 , shows the high performance in job satisfaction and overall 137 and 125 out of $630,21.7 \%$ high performance. It shows the significant change in job performance by job satisfaction.

\subsubsection{Chi-Square of job satisfaction}

Table 4. Chi-Square test of job satisfaction

\begin{tabular}{llll}
\hline Chi-Square Tests & Value & df & Asymp. Sig. (2-sided) \\
& & & .809 \\
\hline Pearson Chi-Square & $1.600^{\mathrm{a}}$ & 4 & .809 \\
Likelihood Ratio & 1.598 & 4 & .727 \\
Linear-by-Linear Association & .122 & 1 & \\
N of Valid Cases & 1000 & &
\end{tabular}

0 cells $(0.0 \%)$ have expected count less than 5 . The minimum expected count is 70.30 .

Table 4 indicate there is significant difference $(\mathrm{P}=.001)$ between job satisfaction of employees in high performance individually with 1000 number of participants. The valid $\mathrm{N}=1000$, among them job satisfaction level of employees situation. However the ratio among them 
is .809 individually. It provided the basic information about the selected variable in job satisfaction involved in employees effects on the basis of employees performance and skills, including the valid (no missing) sample size (n), mean, standard deviation, and standard error, which is based on $\mathrm{N}=100$ no missing observations according to the result. Therefore test result shows the significant.

According to given table the decision regarding the null hypothesis and the outcome of the descripted study. The obtained chi-square value exceeds the critical value, with $\mathrm{df}=4$ and $\alpha=.05$.Therefore the decision is to reject the null hypothesis. The significant result with $x^{2}(2$, $\mathrm{n}=1000)=1.600, \mathrm{p}<.05$. The means that researcher have decided there is a significant relationship between of job performance by job satisfaction level in any organization. However in job satisfaction with minimum expected is 70.30 regarding $\mathrm{df}=4$.

\subsection{Ranking of Extrinsic Rewards}

Table 5. Ranking of Extrinsic rewards of employees

\begin{tabular}{llllllll}
\hline Cross tab of Q2 & \multicolumn{2}{l}{ Ranking } & & & & \\
\hline & Remarks & Outstanding & $\begin{array}{l}\text { High } \\
\text { successful }\end{array}$ & Successful & Marginal & $\begin{array}{l}\text { Need } \\
\text { Improvement }\end{array}$ & Total \\
\cline { 2 - 8 } & & 29 & 34 & 27 & 21 & 27 & 138 \\
$\begin{array}{l}\text { Extrinsic } \\
\text { rewards }\end{array}$ & No & $21.05 \%$ & $24.6 \%$ & $19.6 \%$ & $15.2 \%$ & $19.6 \%$ & $100.0 \%$ \\
& & 184 & 174 & 163 & 170 & 171 & 862 \\
& Yes & $21.3 \%$ & $20.2 \%$ & $18.9 \%$ & $19.7 \%$ & $19.8 \%$ & $100.0 \%$ \\
\hline
\end{tabular}

In the extrinsic rewards the question have shown the outstanding result $21.05 \%$ out of 138 participants individually. $24.6 \%$ in high successful with 34 , which is more than $3.5 \%$ as comparatively outstanding results. However the result shows the high successful rate in case of "No" and in case of "Yes" 184 outstanding participant have accepted the level of performance with all depended variable but in same as above in high successful is 174, its $1.3 \%$ more as comparatively outstanding. This is more than $1 \%$ in high successful. In marginal and need improvement $1.5 \%$ in case of "Yes" and $1.6 \%$ more than from marginal to need improvement. The retention of high performance based advancement opportunities, constituent attachments, extrinsic rewards, flexible work arrangements, job satisfaction, location, non-work influences, organizational commitment, organizational justice, and organizational prestige in dependent variables from which extrinsic rewards is 151 out of 1000 , and $21.3 \%$ out of 862 participants. 


\section{Macrothink}

4.3.1 Graphically view of extrinsic rewards

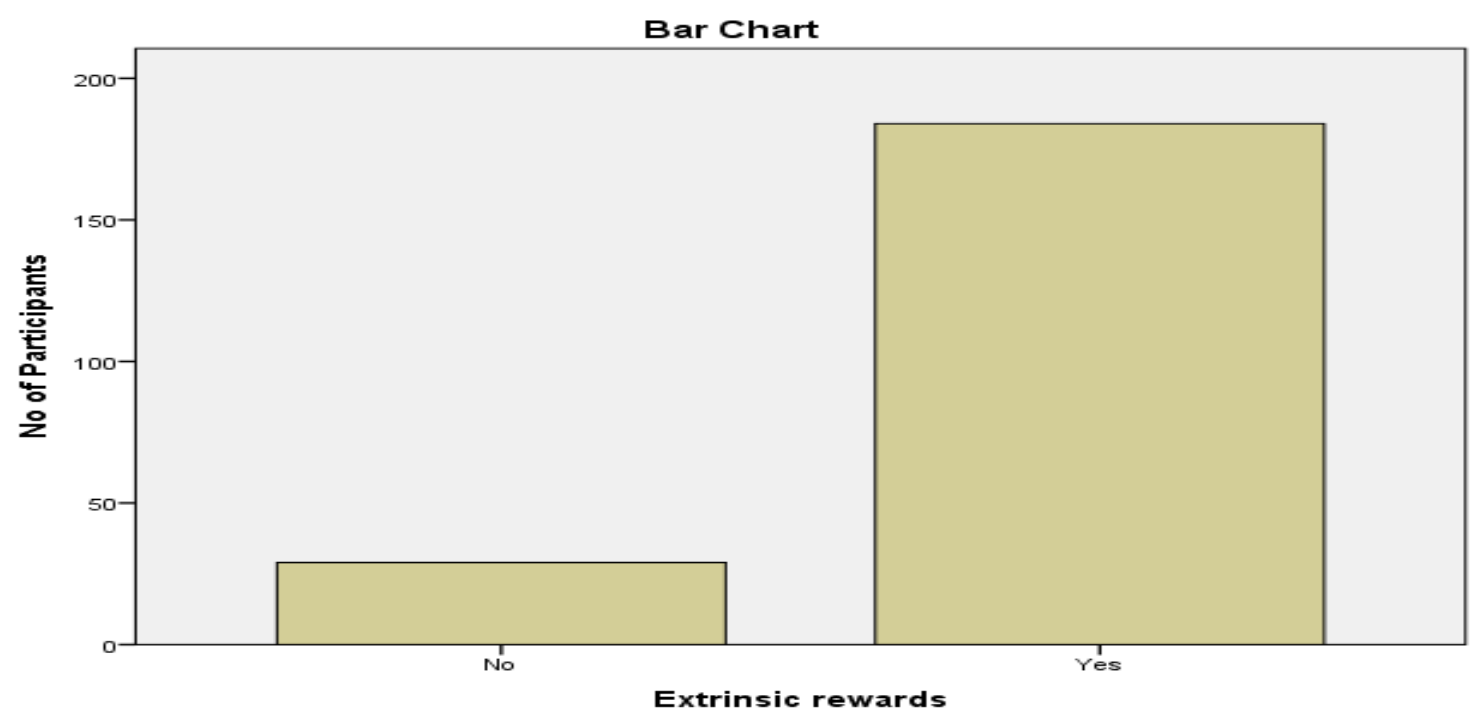

Figure 2. Extrinsic rewards

\subsubsection{Chi-Square of Extrinsic Rewards of Employees}

Table 6. Chi-Square of extrinsic rewards of employees

\section{Chi-Square Tests}

\begin{tabular}{llll} 
& Value & df & Asymp. Sig. (2-sided) \\
\hline Pearson Chi-Square & $2.435^{\mathrm{a}}$ & 4 & .656 \\
Likelihood Ratio & 2.461 & 4 & .652 \\
Linear-by-Linear Association & .455 & 1 & .500 \\
N of Valid Cases & 1000 & & \\
\hline
\end{tabular}

a. 0 cells $(0.0 \%)$ have expected count less than 5 . The minimum expected count is 26.22 .

Table 6 indicate there is significant difference $(\mathrm{P}=.001)$ between extrinsic rewards of employees in high performance individually with 1000 number of participants. The valid $\mathrm{N}=1000$, among them extrinsic rewards level of employees situation. However the ratio among them is .656 individually. It provided the basic information about the selected variable in extrinsic rewards involved in employees effects on the basis of employees performance and skills, including the valid (no missing) sample size (n), mean, standard deviation, and standard error, which is based on $\mathrm{N}=1000$ no missing observations according to the result. Therefore test result shows the significant.

According to given table the decision regarding the null hypothesis and the outcome of the 


\section{Macrothink}

descripted study. The obtained chi-square value exceeds the critical value, with $\mathrm{df}=4$ and $\alpha=.05$. Therefore the decision is to reject the null hypothesis. The significant result with $x^{2}(2$, $\mathrm{n}=1000)=2.435 \mathrm{p}<.05$. The means that researcher have decided there is a significant relationship between of job performance by job satisfaction level in any organization. However in job satisfaction with minimum expected is 26.22 regarding $\mathrm{df}=4$.

\subsection{Ranking of Constituent Attachment}

Table 7. Ranking of Constituent attachment of employees

\begin{tabular}{llllllll}
\hline Cross tab Q-03 & \multicolumn{7}{l}{ Ranking } \\
& Remarks & Outstanding & $\begin{array}{l}\text { High } \\
\text { successful }\end{array}$ & Successful & Marginal & $\begin{array}{l}\text { Need } \\
\text { Improvement }\end{array}$ & Total \\
\cline { 2 - 8 } & & 105 & 99 & 92 & 104 & 90 & 490 \\
\cline { 2 - 7 } $\begin{array}{l}\text { Constituent } \\
\text { attachment }\end{array}$ & No & $21.4 \%$ & $20.2 \%$ & $18.8 \%$ & $21.2 \%$ & $18.4 \%$ & $100.0 \%$ \\
\cline { 2 - 8 } & Yes & 108 & 109 & 98 & 87 & 108 & 510 \\
\cline { 2 - 8 } & $21.2 \%$ & $21.4 \%$ & $19.2 \%$ & $19.8 \%$ & $21.2 \%$ & $100.0 \%$ \\
\hline
\end{tabular}

In the table 06 the constituent attachment of employees have shown the outstanding result $21.4 \%$ out of 490 participants individually. $20.2 \%$ in high successful with 99 , which is more than $1.2 \%$ as comparatively outstanding results. However the result shows the high successful rate in case of "No" and in case of "Yes" 105 outstanding participant have accepted the level of performance with all depended variable but in same as above in high successful is 99, its $1.3 \%$ more as comparatively outstanding. This is more than $1 \%$ in high successful. In marginal and need improvement $1.4 \%$ high, in case of "Yes" and $1.4 \%$ more than from marginal to need improvement. The retention of high performance based constituent attachments in dependent variables from which Constituent attachment is only 3 out of 1000, and $21.2 \%$ out of 510 participants. Therefore the result shows the high performance dependent variable of constituent attachment of employees. 


\section{Macrothink}

\subsubsection{Graphically View}

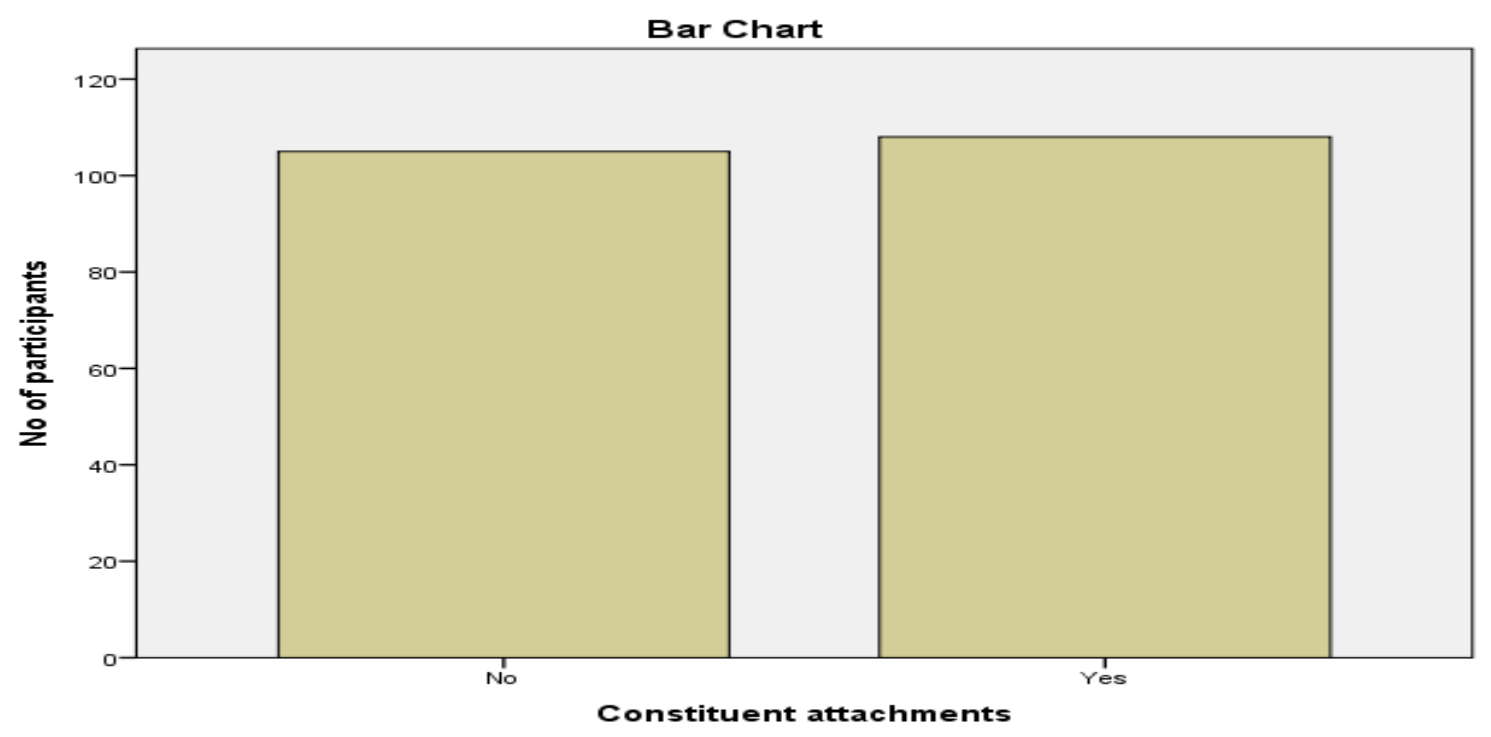

Figure 3. Graphical view of constituent attachment

\subsubsection{Chi-Square of Constituent attachment}

Table 8. Chi-Square of constituent attainment

\section{Chi-Square Tests}

\begin{tabular}{lccc}
\hline & Value & df & Asymp. Sig. (2-sided) \\
\hline Pearson Chi-Square & $3.463^{\mathrm{a}}$ & 4 & .483 \\
Likelihood Ratio & 3.466 & 4 & .483 \\
Linear-by-Linear Association & .008 & 1 & .931 \\
N of Valid Cases & 1000 & & \\
\hline
\end{tabular}

a. 0 cells $(0.0 \%)$ have expected count less than 5 . The minimum expected count is 93.10 .

Table 8 indicate there is significant difference $(\mathrm{P}=.001)$ between constituent attainment of employees in high performance individually with 1000 number of participants. The valid $\mathrm{N}=1000$, among them job satisfaction level of employees situation in constituent attainment. However the ratio among them is .483 individually. It provided the basic information about the selected variable in job satisfaction involved in constituent attainment on the basis of employees performance and skills, including the valid (no missing) sample size (n), mean, standard deviation, and standard error, which is based on $\mathrm{N}=1000$ no missing observations according to the result. Therefore test result shows the significant.

According to given table the decision regarding the null hypothesis and the outcome of the 


\section{Macrothink}

International Journal of Learning and Development

ISSN 2164-4063 2018, Vol. 8, No. 1

descripted study. The obtained chi-square value exceeds the critical value, with $\mathrm{df}=4$ and $\alpha=.05$. Therefore the decision is to reject the null hypothesis. The significant result with $x^{2}(2$, $\mathrm{n}=1000)=3.463, \mathrm{p}<.05$. The means that researcher have decided there is a significant relationship between of job performance by job satisfaction level in any organization by constituent attainment. However in job satisfaction with minimum expected is 93.10 regarding $\mathrm{df}=4$.

\subsection{Ranking of Organization Commitment}

Table 9. Ranking of organization commitment

\begin{tabular}{llllllll}
\hline Cross tab of Q-04 & \multicolumn{2}{c}{ Ranking } \\
\hline \multirow{2}{*}{ Remarks } & Outstanding & $\begin{array}{l}\text { High } \\
\text { successful }\end{array}$ & Successful & Marginal & $\begin{array}{l}\text { Need } \\
\text { Improvement }\end{array}$ & Total \\
\cline { 2 - 7 } & No & 139 & 151 & 132 & 133 & 144 & 699 \\
\cline { 2 - 7 } Org-Comm & $19.9 \%$ & $21.6 \%$ & $18.9 \%$ & $19.0 \%$ & $20.6 \%$ & $100 \%$ \\
\cline { 2 - 8 } & Yes & 74 & 57 & 58 & 58 & 54 & 301 \\
\cline { 2 - 7 } & & $21.3 \%$ & $20.8 \%$ & $19.0 \%$ & $19.1 \%$ & $19.9 \%$ & $100 \%$ \\
\hline
\end{tabular}

In the organizational commitment have shown the outstanding result $19.9 \%$ out of 699 participants individually. $21.6 \%$ in high successful with 151 out of 699 , which is more than $1.7 \%$ as comparatively outstanding results. However the result shows the high successful rate in case of "No" and in case of "Yes" 74 outstanding participant have accepted the level of performance with all depended variable but in same as above in high successful is 57 with $20.8 \%$, its $1.4 \%$ more as comparatively outstanding. This is more than $1 \%$ in high successful. In marginal and need improvement 1.4\% high, in case of "Yes" and like 1.6\% more than from marginal to need improvement. The retention of high performance based organizational commitment in dependent variables from which Constituent attachment is only 65 out of 1000 , and $21.3 \%$ out of 301 participants. Therefore the result shows the high performance dependent variable of organizational commitment of employees. 


\subsubsection{Graphically View of Organization Commitment}

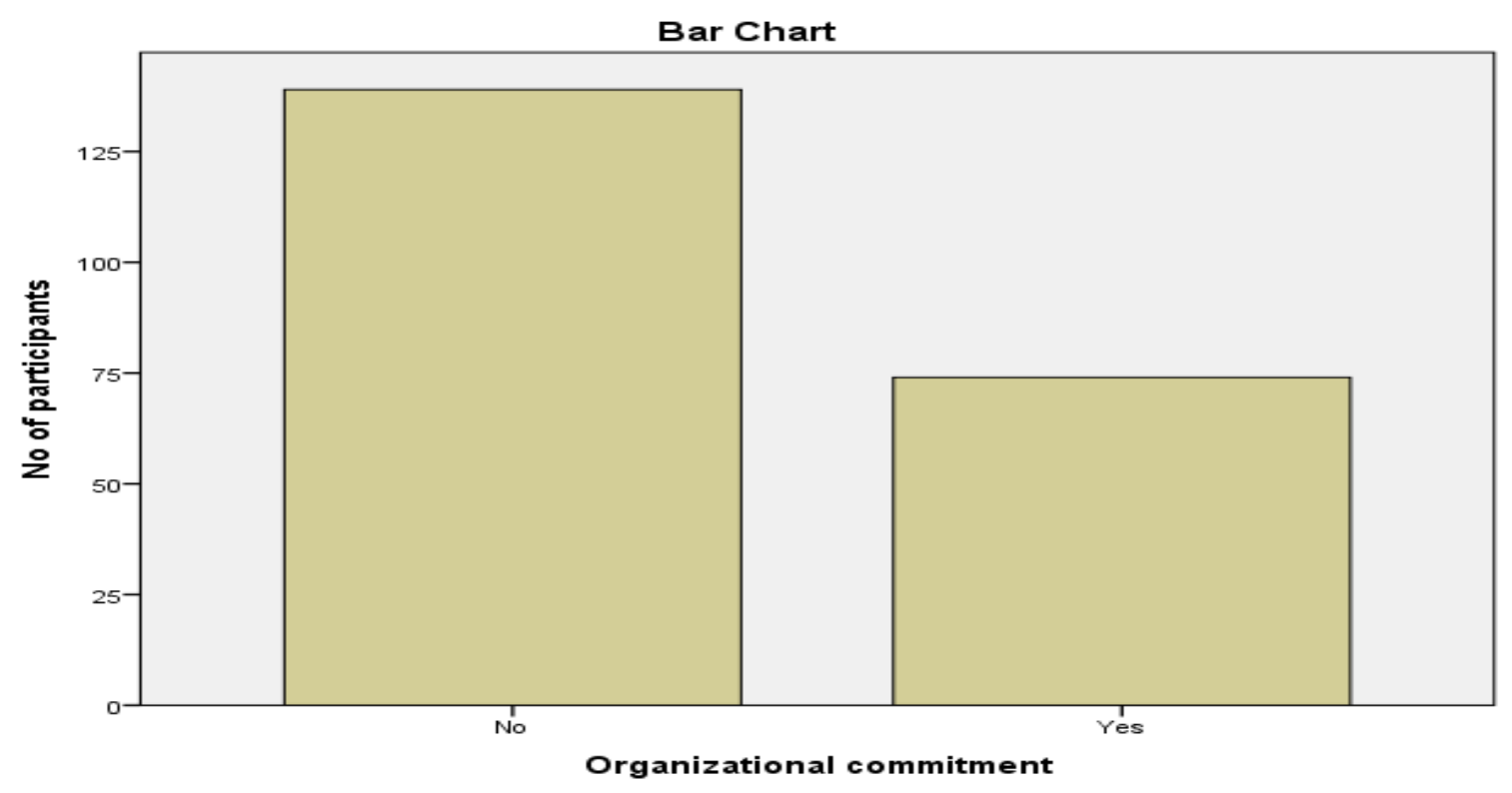

Figure 4. Organization Commitment

In the bar chart the number of participants variation is 139 to 74 , shows the high performance in extrinsic reward and overall 139 and 74 out of $301.53 .2 \%$ high performance. It shows the significant change in job performance by organization commitment.

\subsubsection{Chi-Square of Organization Commitment}

Table 10. Chi-Square of organization commitment

\begin{tabular}{lccc}
\hline Chi-Square Tests & Value & df & Asymp. Sig. (2-sided) \\
\hline Pearson Chi-Square & $3.675^{\mathrm{a}}$ & 4 & .452 \\
Likelihood Ratio & 3.644 & 4 & .456 \\
Linear-by-Linear Association & 1.437 & 1 & .231 \\
N of Valid Cases & 1000 & & \\
\hline
\end{tabular}

a. 0 cells $(0.0 \%)$ have expected count less than 5 . The minimum expected count is 57.19 .

Table 10 indicates there is significant difference $(\mathrm{P}=.001)$ between job satisfaction of employees in high performance individually with 1000 number of participants in organization commitments. The valid $\mathrm{N}=1000$, among them job satisfaction level of employees situation. However the ratio among them is .452 individually. It provided the basic information about the selected variable in job satisfaction involved in employees effects on the basis of employees performance with organization commitment and skills, including the valid (no 
missing) sample size (n), mean, standard deviation, and standard error, which is based on $\mathrm{N}=1000$ no missing observations according to the result. Therefore test result shows the significant.

According to given table the decision regarding the null hypothesis and the outcome of the descripted study. The obtained chi-square value exceeds the critical value, with $\mathrm{df}=4$ and $\alpha=.05$. Therefore the decision is to reject the null hypothesis. The significant result with $\mathrm{x}^{2}(2$, $\mathrm{n}=1000)=3.675, \mathrm{p}<.05$. The means that researcher have decided there is a significant relationship between of job performance by job satisfaction level in any organization. However in job satisfaction with minimum expected is 57.19 regarding $\mathrm{df}=4$.

\subsection{Ranking of Organization Prestige}

Table 11. Ranking of organization prestige

\begin{tabular}{|c|c|c|c|c|c|c|c|}
\hline \multicolumn{2}{|c|}{ Cross tab of Q 05} & \multicolumn{6}{|l|}{ Ranking } \\
\hline & Remarks & Outstanding & $\begin{array}{l}\text { High } \\
\text { successful }\end{array}$ & Successful & Marginal & $\begin{array}{l}\text { Need } \\
\text { Improvement }\end{array}$ & $\mathrm{T}$ \\
\hline \multirow{4}{*}{$\begin{array}{l}\text { Organization } \\
\text { prestige }\end{array}$} & No & 123 & 123 & 114 & 102 & 128 & 590 \\
\hline & & $20.8 \%$ & $20.8 \%$ & $19.3 \%$ & $17.3 \%$ & $21.7 \%$ & $100.0 \%$ \\
\hline & Yes & 90 & 85 & 76 & 89 & 70 & 410 \\
\hline & & $22.0 \%$ & $21.7 \%$ & $18.5 \%$ & $21.7 \%$ & $17.1 \%$ & $100.0 \%$ \\
\hline
\end{tabular}

In the organization prestige have shown the outstanding result $123 \%$ out of 590 participants individually. $20.8 \%$ in high successful with 123 out of 590, which is same as comparatively outstanding results. However the result shows the high successful rate in case of "No" and in case of "Yes" 33 outstanding participant have accepted the level of performance with all depended variable but in same as above in high successful is 82 with $21.7 \%$, its $0.3 \%$ more as comparatively outstanding. This is more than $1 \%$ in high successful. In marginal and need improvement $2.4 \%$ high, in case of "Yes" and like 2.6\% more than from marginal to need improvement. The retention of high performance based organizational commitment in dependent variables from which organization prestige is only 33 out of 1000 , and $21.7 \%$ out of 410 participants. Therefore the result shows the high performance dependent variable of organization prestige of employees. 
4.6.1 Graphically View of Organization Prestige

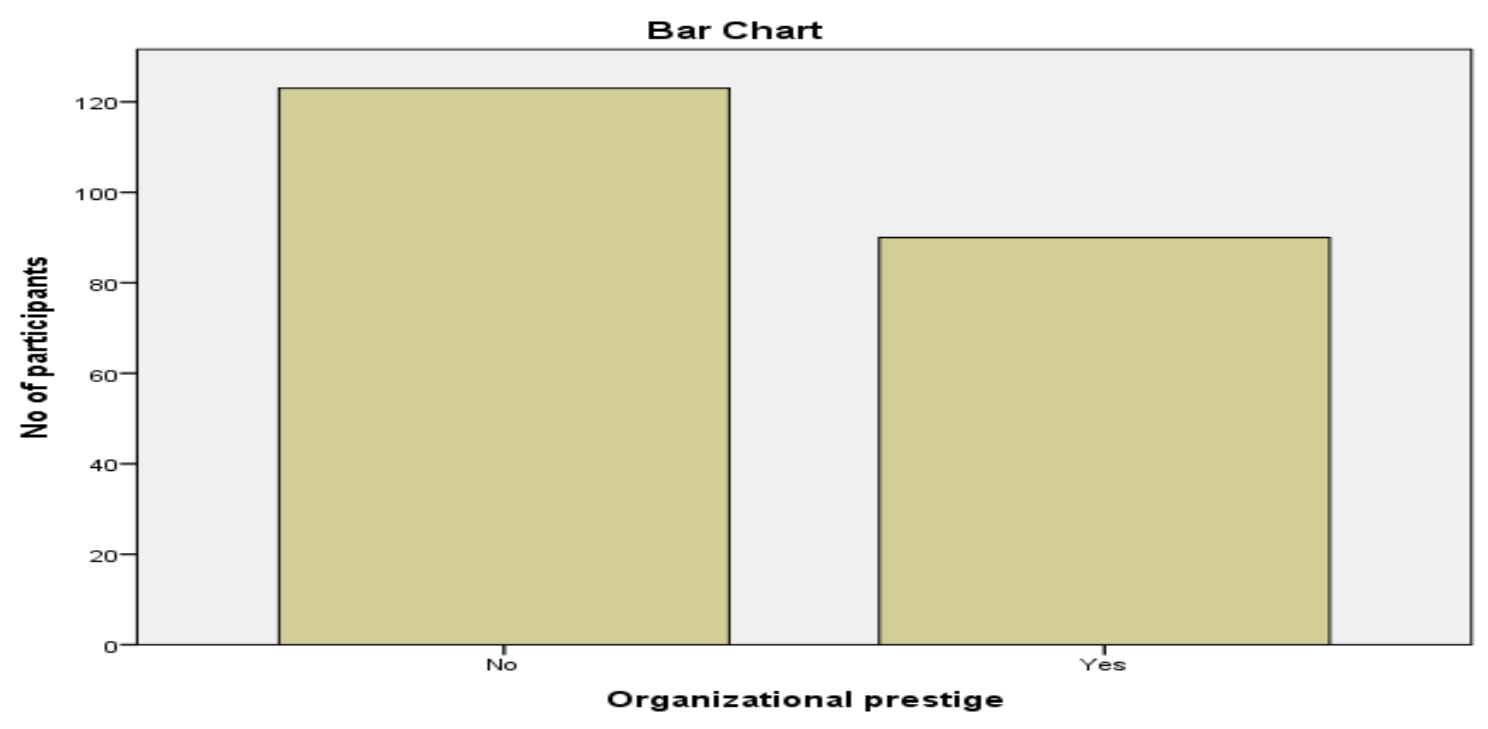

Figure 5. Organization Prestige

In the bar chart the number of participants variation is 123 to 90 , shows the high performance in extrinsic reward and overall 123 and 90 out of 410, 21.95\% high performance. It shows the significant change in job performance by organization prestige.

\subsubsection{Chi-Square of Organization Prestige}

Table 12. Chi-Square of organization prestige

\begin{tabular}{lccc}
\hline Chi-Square Tests & & & \\
\hline & Value & $\mathrm{df}$ & Asymp. Sig. (2-sided) \\
\hline Pearson Chi-Square & $5.301^{\mathrm{a}}$ & 4 & .258 \\
\hline Likelihood Ratio & 5.316 & 4 & .256 \\
\hline Linear-by-Linear Association & .566 & 1 & .452 \\
\hline N of Valid Cases & 1000 & & \\
\hline
\end{tabular}

a. 0 cells $(0.0 \%)$ have expected count less than 5 . The minimum expected count is 77.90 .

Table 12 indicates there is significant difference $(\mathrm{P}=.001)$ between job satisfaction of employees in high performance individually with 1000 number of participants in organization prestige. The valid $\mathrm{N}=1000$, among them job satisfaction level of employees situation. However the ratio among them is .258 individually by organization prestige. It provided the basic information about the selected variable in job satisfaction involved in employees effects on the basis of employees performance and skills, including the valid (no missing) sample 
size (n), mean, standard deviation, and standard error, which is based on $\mathrm{N}=100$ no missing observations according to the result. Therefore test result shows the significant.

According to given table the decision regarding the null hypothesis and the outcome of the descripted study. The obtained chi-square value of organization prestige exceeds the critical value, with $\mathrm{df}=4$ and $\alpha=.05$.Therefore the decision is to reject the null hypothesis. The significant result with $\mathrm{x}^{2}(2, \mathrm{n}=1000)=5.301, \mathrm{p}<.05$. The means that researcher have decided there is a significant relationship between of job performance by job satisfaction level in organization prestige in any organization. However in job satisfaction with minimum expected is 70.90 regarding $\mathrm{df}=4$.

\subsection{Ranking of Advancement}

Table 13. Ranking of advancement

\begin{tabular}{llllllll}
\hline Cross tab of Q-08 & \multicolumn{2}{l}{ Ranking } & & & & \\
& Remarks & Outstanding & $\begin{array}{l}\text { High } \\
\text { successful }\end{array}$ & Successful & Marginal & $\begin{array}{l}\text { Need } \\
\text { Improvement }\end{array}$ & Total \\
& No & 154 & 161 & 144 & 145 & 157 & 761 \\
\cline { 2 - 8 } Advan- & & $20.2 \%$ & $21.2 \%$ & $18.9 \%$ & $19.1 \%$ & $20.6 \%$ & $100.0 \%$ \\
\cline { 2 - 8 } cement & Yes & 59 & 47 & 46 & 46 & 41 & 239 \\
\cline { 2 - 8 } & & $24.7 \%$ & $19.7 \%$ & $19.2 \%$ & $19.2 \%$ & $17.2 \%$ & $100.0 \%$ \\
\hline
\end{tabular}

In the advancement chart have shown the outstanding result $20.2 \%$ out of 761 participants individually. $161 \%$ in high successful with 161 out of 761 , which is more than $1.2 \%$ as comparatively outstanding results in remark of "No". However the result shows the high successful rate in case of "No" and in case of "Yes" 59 outstanding participant have accepted the level of performance with all depended variable but in same as above in high successful is 47 with $19.7 \%$, its $5 \%$ less as comparatively outstanding result individually. This is more than $5 \%$ less in high successful. In marginal and need improvement $1.7 \%$ high, in case of "Yes" and like $1.6 \%$ less than from marginal to need improvement. The retention of high performance based advertisement in dependent variables from which advertisement is only 105 out of 1000 , and $54.7 \%$ out of 739 participants. Therefore the result shows the high performance dependent variable of advancement employees. 
4.7.1 Graphically View of Advancement

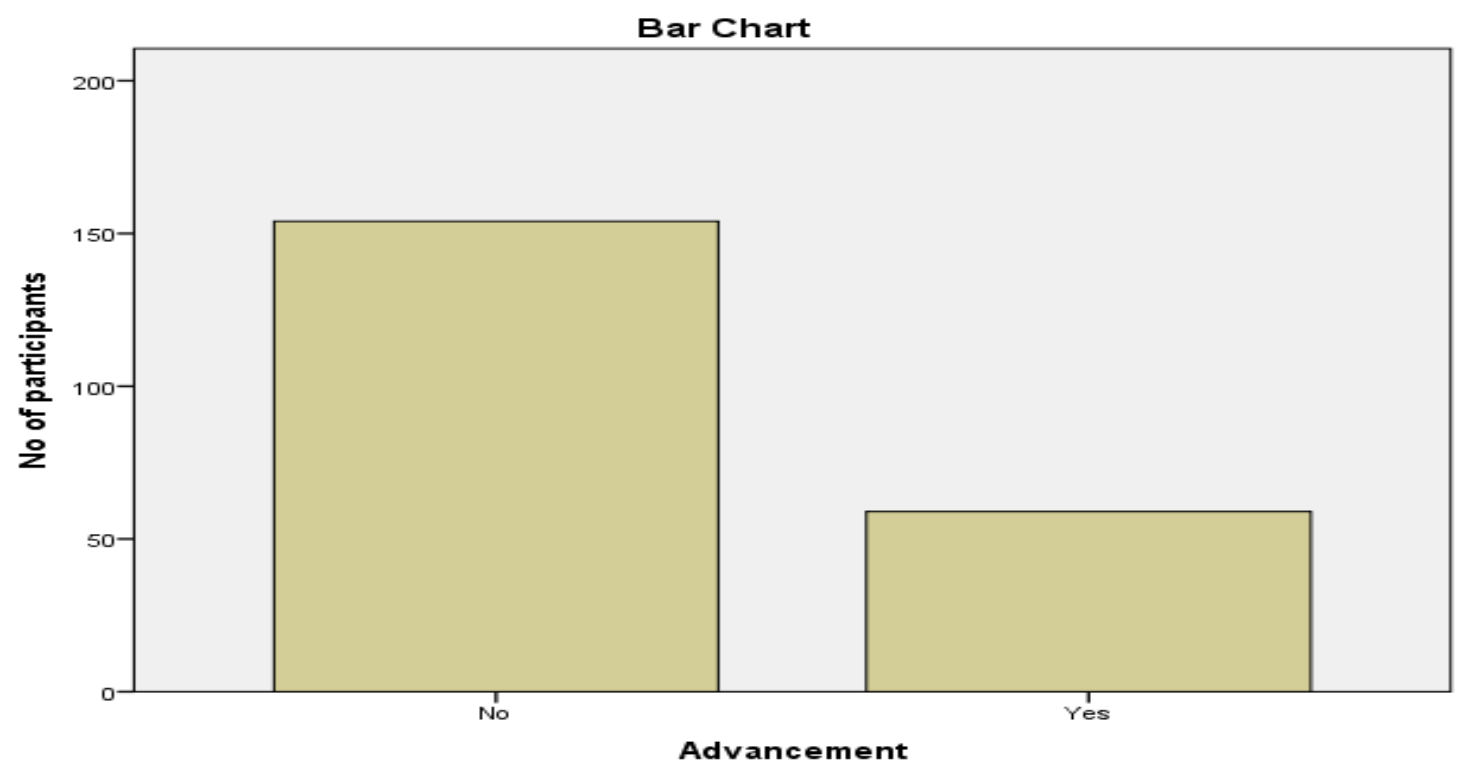

Figure 6. Advancement

In the bar chart the number of participants variation is 154 to 59 , shows the high performance in extrinsic reward and overall 154 and 59 out of 239, 24.6\% high performance. It shows the significant change in job performance by advancement.

\subsubsection{Chi-Square of Advancement}

Table 14. Chi-Square of advancement

\begin{tabular}{lccc}
\hline Chi-Square Tests & Value & df & Asymp. Sig. (2-sided) \\
\hline Pearson Chi-Square & $3.710^{\text {a }}$ & 4 & .447 \\
\hline Likelihood Ratio & 3.706 & 4 & .447 \\
\hline Linear-by-Linear Association & 2.032 & 1 & .154 \\
\hline N of Valid Cases & 1000 & & \\
\hline
\end{tabular}

a. 0 cells $(0.0 \%)$ have expected count less than 5 . The minimum expected count is 74.86 .

Table 13 indicate there is significant difference $(\mathrm{P}=.001)$ between job satisfaction of employees in high performance individually with 1000 number of participants in advancement. The valid $\mathrm{N}=1000$, among them job satisfaction level of employees situation. However the ratio among them is .447 individually. It provided the basic information about the selected variable in job satisfaction involved in employees effects on the basis of employees performance and skills in advancement, including the valid (no missing) sample size (n), mean, standard deviation, and standard error, which is based on $\mathrm{N}=1000$ no missing observations according to the result. Therefore test result shows the significant. 


\section{Macrothink}

International Journal of Learning and Development

ISSN 2164-4063 2018, Vol. 8, No. 1

According to given table the decision regarding the null hypothesis and the outcome of the descripted study. The obtained chi-square value exceeds the critical value, with $\mathrm{df}=4$ and $\alpha=.05$.Therefore the decision is to reject the null hypothesis. The significant result with $x^{2}(2$, $\mathrm{n}=1000)=3.710, \mathrm{p}<.05$. The means that researcher have decided there is a significant relationship between of job performance by advancement level in any organization. However in job satisfaction with minimum expected is 74.86 regarding $\mathrm{df}=4$.

\subsection{Ranking of Location}

Table 15. Ranking of location

\begin{tabular}{rlllllll}
\hline Cross tab of Q-9 & \multicolumn{2}{l}{ Ranking } & & & & \\
\hline & Remarks & Outstanding & $\begin{array}{l}\text { High } \\
\text { successful }\end{array}$ & Successful & Marginal & $\begin{array}{l}\text { Need } \\
\text { Improvement }\end{array}$ & Total \\
\cline { 2 - 7 } & No & 119 & 130 & 114 & 115 & 128 & 606 \\
\cline { 2 - 7 } Location & $19.6 \%$ & $21.5 \%$ & $18.8 \%$ & $19 \%$ & $21.2 \%$ & $100.0 \%$ \\
\cline { 2 - 7 } & Yes & 94 & 78 & 76 & 76 & 70 & 394 \\
\cline { 2 - 7 } & $23.9 \%$ & $19.8 \%$ & $19.3 \%$ & $19.3 \%$ & $17.8 \%$ & $100.0 \%$ \\
\hline
\end{tabular}

In dependent variable location of employees have shown the outstanding result $19.6 \%$ out of 606 participants individually. $21.5 \%$ in high successful with 130 out of 606 , which is comparatively more than $1.9 \%$ as comparatively outstanding results in remark of "No". However the result shows the high successful rate in case of "No" and in case of "Yes" 94 outstanding participant have accepted the level of performance with all depended variable but in same as above in high successful is 78 with $19.8 \%$, its $4.2 \%$ more as comparatively outstanding result individually. This is more than $4.2 \%$ less in high successful. In marginal and need improvement $2.9 \%$ high, in case of "Yes" and like $2.2 \%$ less than from marginal to need improvement. The retention of high performance based location of employee in dependent variables from which location effects is only 25 out of 1000 , and $23.3 \%$ out of 394 participants. Therefore the result shows the high performance dependent variable of location of employees. 


\section{Macrothink}

4.8.1 Graphically view of location

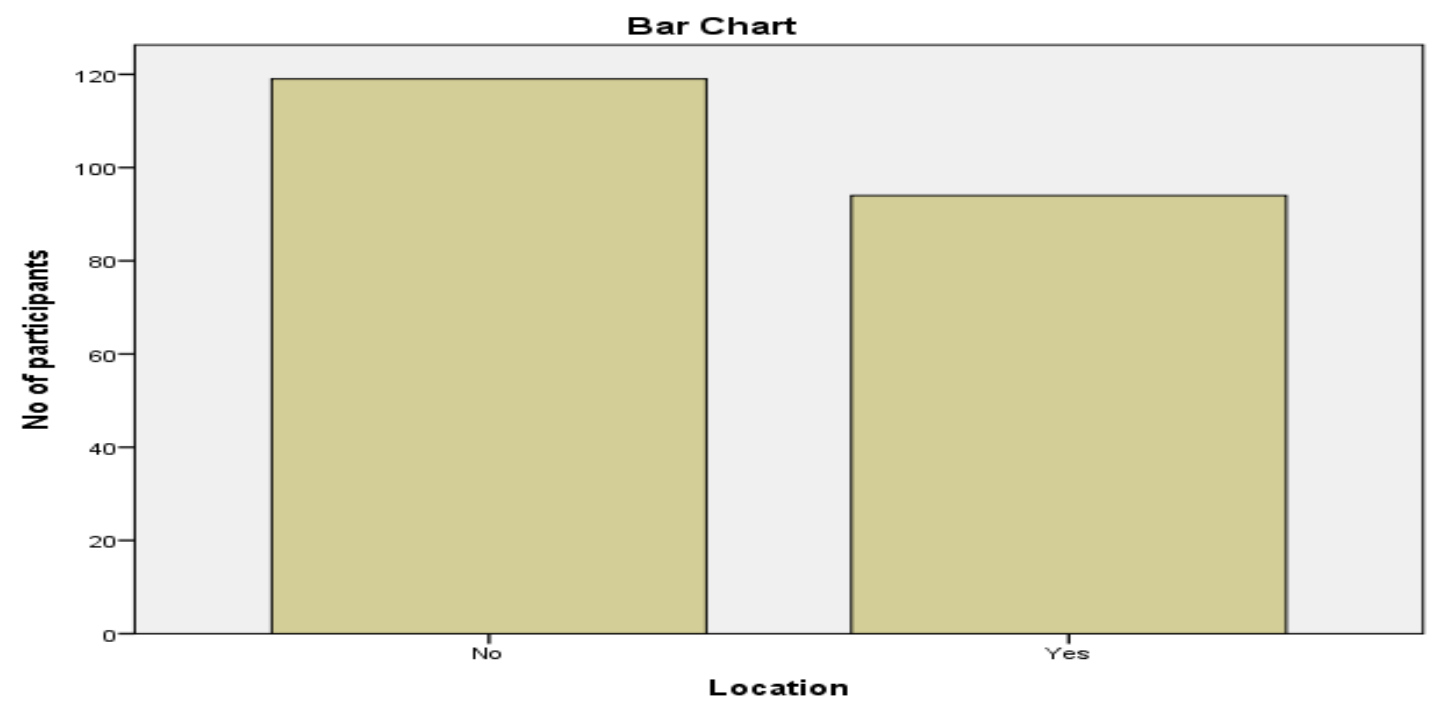

Figure 7. Location

In the bar chart the number of participants variation is 119 to 94 , shows the high performance in extrinsic reward and overall 119 and 94 out of $94,21.2 \%$ high performance. It shows the significant change in job performance by location.

\subsubsection{Chi-Square of Location}

Table 16. Chi-Square of location

\section{Chi-Square Tests}

\begin{tabular}{lccc} 
& Value & df & Asymp. Sig. (2-sided) \\
\hline Pearson Chi-Square & $3.710^{\mathrm{a}}$ & 4 & .447 \\
\hline Likelihood Ratio & 3.706 & 4 & .447 \\
\hline Linear-by-Linear Association & & & .154 \\
\hline N of Valid Cases & 2.032 & 1 & \\
\hline
\end{tabular}

a. 0 cells $(0.0 \%)$ have expected count less than 5 . The minimum expected count is 74.86 .

Table 16 indicates there is significant difference $(\mathrm{P}=.001)$ between job satisfaction of employees in high performance individually with 1000 number of participants in by location. The valid $\mathrm{N}=1000$, among them job satisfaction level of employees situation. However the ratio among them is .447 individually. It provided the basic information about the selected variable in job satisfaction involved in employees effects on the basis of employees 
performance and skills, including the valid (no missing) sample size (n), mean, standard deviation, and standard error, which is based on $\mathrm{N}=1000$ no missing observations according to the result. Therefore test result shows the significant.

According to given table the decision regarding the null hypothesis and the outcome of the descripted study. The obtained chi-square value exceeds the critical value, with $\mathrm{DF}=4$ and $\alpha=.05$. Therefore the decision is to reject the null hypothesis. The significant result with $x^{2}(2$, $\mathrm{n}=1000)=3.710, \mathrm{p}<.05$. The means that researcher have decided there is a significant relationship between of job performance by location of employees in any organization. However in job satisfaction with minimum expected is 74.86 regarding $\mathrm{df}=4$.

\subsection{Ranking of Organization Justices}

Table 16. Ranking of organization justice

\begin{tabular}{llllllll}
\hline Cross tab of Q-10 & \multicolumn{2}{l}{ Ranking } & & & & \\
& Remarks & Outstanding & $\begin{array}{l}\text { High } \\
\text { successful }\end{array}$ & Successful & Marginal & $\begin{array}{l}\text { Need } \\
\text { Improvement }\end{array}$ & Total \\
\cline { 2 - 8 } & No & 152 & 159 & 141 & 150 & 148 & 750 \\
\cline { 2 - 8 } Org-Justice & $20.3 \%$ & $21.2 \%$ & $18.8 \%$ & $20.0 \%$ & $19.7 \%$ & $100.0 \%$ \\
\cline { 2 - 8 } & Yes & 61 & 49 & 49 & 41 & 50 & 250 \\
\cline { 2 - 8 } & $24.4 \%$ & $19.6 \%$ & $19.6 \%$ & $16.4 \%$ & $20.0 \%$ & $100.0 \%$ \\
\hline
\end{tabular}

In dependent variable organization justices of employees have shown the outstanding result $20.3 \%$ out of 750 participants individually. $21.2 \%$ in high successful with 159 out of 750 , which is comparatively more than $1.5 \%$ as comparatively less outstanding results in remark of "No". However the result shows the high successful rate in case of "No" and in case of "Yes" 61 outstanding participant have accepted the level of performance with all depended variable but in same as above in high successful is 49 with $19.6 \%$, its $4.8 \%$ less as comparatively outstanding result individually. This is more than $4.8 \%$ less in high successful. In marginal and need improvement $1.3 \%$ high need improvement comparatively, in case of "Yes" and like 4.8\% more than from marginal to need improvement. The retention of high performance based location of employee in dependent variables from which location effects is only 91 out of 1000 , and $19.6 \%$ out of 250 participants. Therefore the result shows the high performance dependent variable of organization justice of employees. 
4.9.1 Graphically View of Organization Justices

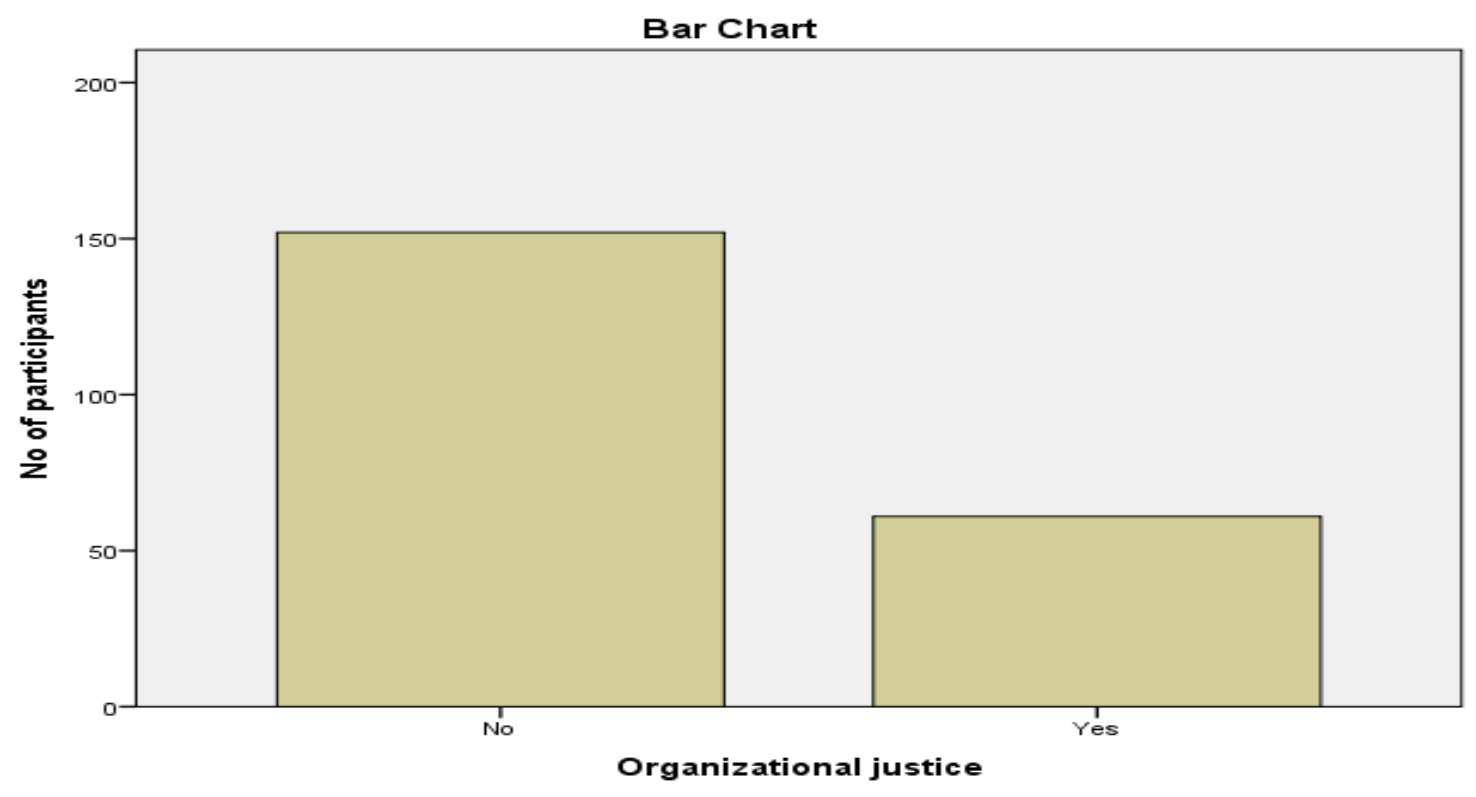

Figure 8. Organization Justices

In the bar chart the number of participants variation is 152 to 61 , shows the high performance in extrinsic reward and overall 152 and 61 out of $250,48.2 \%$ high performance. It shows the significant change in job performance by organization justices.

\subsubsection{Chi-Square of Organization Justices}

Table 17. Chi-Square of organization justices

\section{Chi-Square Tests}

\begin{tabular}{lccc} 
& Value & df & Asymp. Sig. (2-sided) \\
\hline Pearson Chi-Square & $3.077^{\mathrm{a}}$ & 4 & .545 \\
\hline Likelihood Ratio & 3.078 & 4 & .545 \\
\hline Linear-by-Linear Association & .870 & 1 & .351 \\
\hline N of Valid Cases & 1000 & &
\end{tabular}

a. 0 cells $(0.0 \%)$ have expected count less than 5 . The minimum expected count is 47.50 .

Table 17 indicate there is significant difference $(\mathrm{P}=.001)$ between job satisfaction of employees in high performance individually with 1000 number of participants in organization justices. The valid $\mathrm{N}=1000$, among them job satisfaction level of employees situation. However the ratio among them is .545 individually. It provided the basic information about the selected variable in job satisfaction involved in employees effects on the basis of 
employees performance and skills by organization justices, including the valid (no missing) sample size (n), mean, standard deviation, and standard error, which is based on $\mathrm{N}=1000$ no missing observations according to the result. Therefore test result shows the significant.

According to given table the decision regarding the null hypothesis and the outcome of the descripted study. The obtained chi-square value exceeds the critical value, with $\mathrm{df}=4$ and $\alpha=.05$. Therefore the decision is to reject the null hypothesis. The significant result with $x^{2}(2$, $\mathrm{n}=1000)=5.45, \mathrm{p}<.05$. The means that researcher have decided there is a significant relationship between of job performance by job satisfaction level in any organization in organization justices. However in job satisfaction with minimum expected is 47.50 regarding $\mathrm{df}=4$.

\subsection{Ranking of Flexible Work}

Table 19. Ranking of flexible work

\begin{tabular}{|c|c|c|c|c|c|c|c|}
\hline \multicolumn{2}{|c|}{ Cross tab of Q-11 } & \multicolumn{6}{|l|}{ Ranking } \\
\hline & Remarks & Outstanding & $\begin{array}{l}\text { High } \\
\text { successful }\end{array}$ & Successful & Marginal & $\begin{array}{l}\text { Need } \\
\text { Improvement }\end{array}$ & Total \\
\hline \multirow{4}{*}{$\begin{array}{l}\text { Flexible } \\
\text { work }\end{array}$} & No & 97 & 101 & 94 & 78 & 108 & 478 \\
\hline & & $20.3 \%$ & $21.1 \%$ & $19.7 \%$ & $16.3 \%$ & $22.6 \%$ & $100.0 \%$ \\
\hline & Yes & 116 & 107 & 96 & 113 & 90 & 522 \\
\hline & & $22.2 \%$ & $20.5 \%$ & $18.4 \%$ & $21.6 \%$ & $17.2 \%$ & $100.0 \%$ \\
\hline
\end{tabular}

In dependent variable flexible work of employees have shown the outstanding result $20.3 \%$ out of 478 participants individually. $21.2 \%$ in high successful with 101 out of 478 , which is comparatively more than $1.8 \%$ as comparatively outstanding results in remark of "No". However the result shows the high successful rate in case of "No" and in case of "Yes" 116 outstanding participant have accepted the level of performance with all depended variable but in same as above in high successful is 107 with $20.5 \%$, its $2.7 \%$ less as comparatively outstanding result individually. This is more than $2.7 \%$ less in high successful. In marginal and need improvement $6.3 \%$ high, in case of "Yes" and like $4.8 \%$ less than from marginal to need improvement. The retention of high performance based flexible of employee in dependent variables from which location effects is only 119 out of 1000 , and $20.5 \%$ out of 522 participants. Therefore the result shows the high performance dependent variable of flexible work of employees. 
4.10.1 Graph of Flexible Work

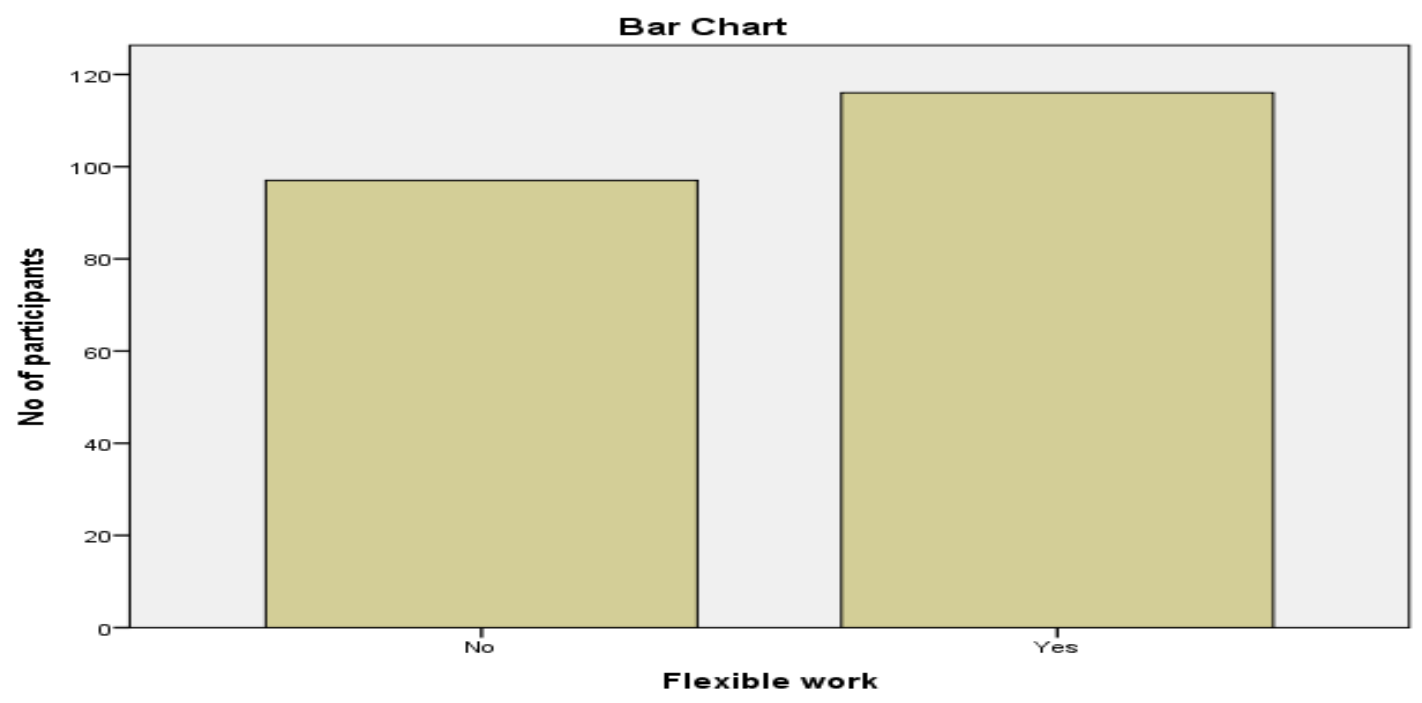

Figure 9. Flexible Work

In the bar chart the number of participants variation is 97 to 116 , shows the high performance in extrinsic reward and overall 97 and 116 out of 522, 83.6\% high performance. It shows the significant change in job performance by flexible work.

4.10.2 Chi-Square of Flexible Work

Table 20. Chi-Square of flexible work

\begin{tabular}{lccc}
\hline Chi-Square Tests & & & \\
\hline & Value & df & Asymp. Sig. (2-sided) \\
\hline Pearson Chi-Square & $8.018^{\mathrm{a}}$ & 4 & .091 \\
\hline Likelihood Ratio & 8.043 & 4 & .090 \\
\hline Linear-by-Linear Association & .904 & 1 & .342 \\
\hline N of Valid Cases & 1000 & & \\
\hline
\end{tabular}

a. 0 cells $(0.0 \%)$ have expected count less than 5 . The minimum expected count is 90.82 .

Table 20 indicates there is significant difference $(\mathrm{P}=.001)$ between job satisfaction of employees in high performance individually with 1000 number of participants flexible work. The valid $\mathrm{N}=1000$, among them job satisfaction level of employees situation. However the ratio among them is .091 individually. It provided the basic information about the selected variable in job satisfaction involved in employees effects on the basis of employees performance and skills in flexible work, including the valid (no missing) sample size (n), 
mean, standard deviation, and standard error, which is based on $\mathrm{N}=1000$ no missing observations according to the result. Therefore test result shows the significant.

According to given table the decision regarding the null hypothesis and the outcome of the descripted study. The obtained chi-square value exceeds the critical value, with $\mathrm{df}=4$ and $\alpha=.05$. Therefore the decision is to reject the null hypothesis. The significant result with $x^{2}(2$, $\mathrm{n}=1000)=8.018, \mathrm{p}<.05$. The means that researcher have decided there is a significant relationship between of job performance by job satisfaction level in any organization in flexible work. However in job satisfaction with minimum expected is 92.80 regarding $\mathrm{df}=4$.

\subsection{Ranking of Non-Work Influence}

Table 21. Ranking of non-influence

\begin{tabular}{llllllll}
\hline Cross tab of Q-12 & \multicolumn{2}{l}{ Ranking } & & & & \\
\hline \multirow{2}{*}{$\begin{array}{l}\text { Non-work } \\
\text { influence }\end{array}$} & Remarks & Outstanding & $\begin{array}{l}\text { High } \\
\text { successful }\end{array}$ & Successful & Marginal & $\begin{array}{l}\text { Need } \\
\text { Improvement }\end{array}$ & Total \\
\cline { 2 - 8 } & No & 103 & 106 & 98 & 86 & 117 & 510 \\
\cline { 2 - 8 } & $20.2 \%$ & $20.8 \%$ & $19.2 \%$ & $16.9 \%$ & $22.9 \%$ & $100.0 \%$ \\
\cline { 2 - 8 } & Yes & 110 & 102 & 92 & 105 & 81 & 490 \\
\cline { 2 - 8 } & $22.4 \%$ & $20.8 \%$ & $18.8 \%$ & $21.4 \%$ & $16.5 \%$ & $100.0 \%$ \\
\hline
\end{tabular}

In dependent variable location of employees have shown the outstanding result $20.2 \%$ out of 510 participants individually. $20.8 \%$ in high successful with 106 out of 510, which is comparatively more than $0.6 \%$ as comparatively outstanding results in remark of "No". However the result shows the high successful rate in case of "No" and in case of "Yes" 110 outstanding participant have accepted the level of performance with all depended variable but in same as above in high successful is 102 with $20.8 \%$, its $2 \%$ less comparatively outstanding result individually. This is more than $2 \%$ less in high successful. In marginal and need improvement $6 \%$ high, in case of "Yes" and like 4.9\% less than from marginal to need improvement. The retention of high performance based location of employee in dependent variables from which location effects is only 7 out of 1000 , and $20.8 \%$ out of 490 participants. Therefore the result shows the high performance dependent variable of non-work influence of employees. 
4.11.1 Graphically View of Non-Influence

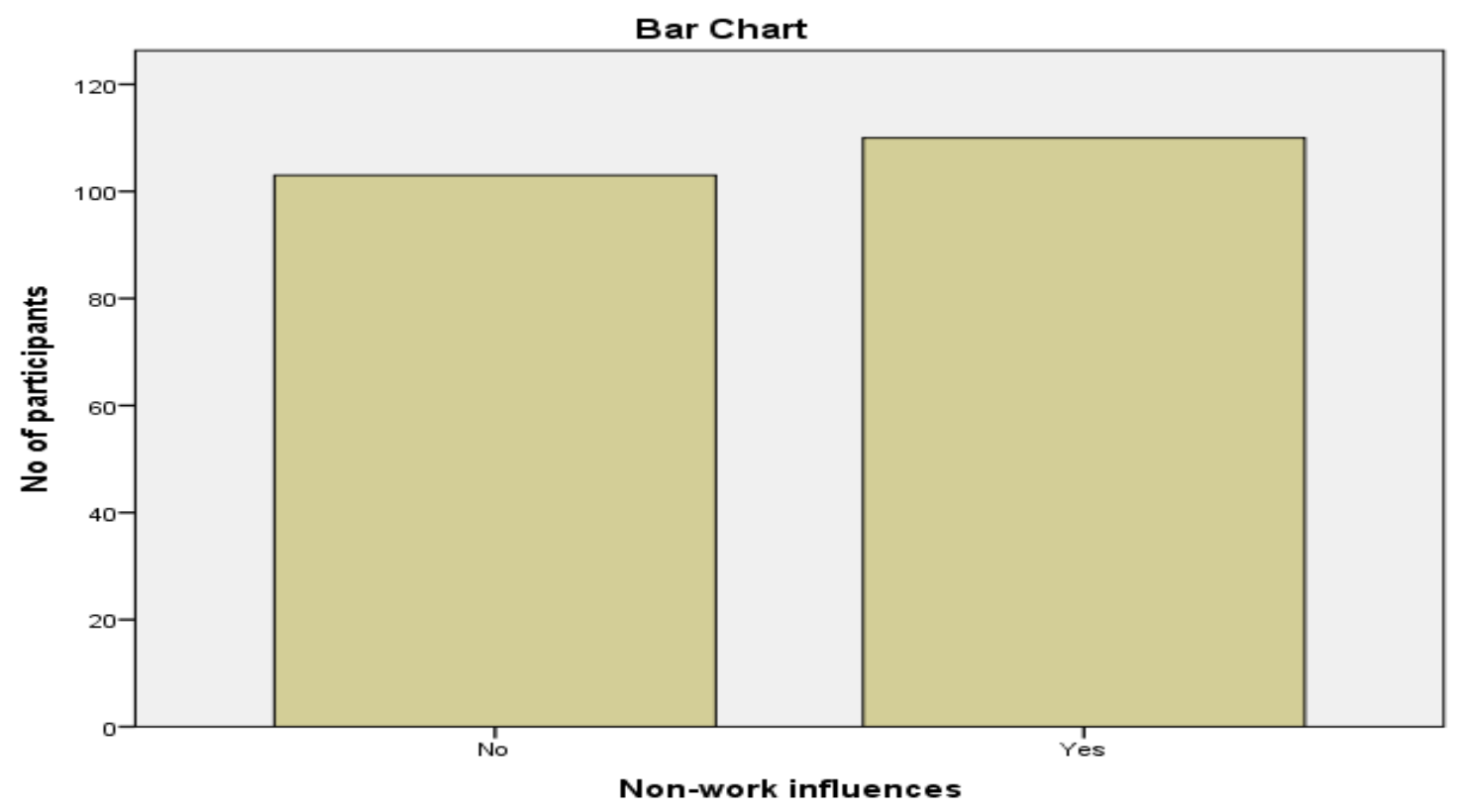

Figure 10. Non-Work influence

In the bar chart the number of participants variation is 103 to 110 , shows the high performance in extrinsic reward and overall 103 and 110 out of $490,0.2 \%$ high performance. It shows the significant change in job performance by non-work influence.

\subsubsection{Chi-Square of Non-Work Influence}

Table 22. Chi-Square of non-work influence

\begin{tabular}{lccc}
\hline \multicolumn{1}{l}{ Chi-Square Tests } & & \\
\hline & Value & $\mathrm{df}$ & Asymp. Sig. (2-sided) \\
\hline Pearson Chi-Square & $8.535^{\mathrm{a}}$ & 4 & .074 \\
\hline Likelihood Ratio & 8.572 & 4 & .073 \\
\hline Linear-by-Linear Association & 2.002 & 1 & .157 \\
\hline N of Valid Cases & 1000 & & \\
\hline a. 0 cells $(0.0 \%)$ have expected count less than 5. The minimum expected count is 93.10.
\end{tabular}

Table 22 indicates there is significant difference $(\mathrm{P}=.001)$ between job satisfaction of employees in high performance individually with 1000 number of participants non-work influence. The valid $\mathrm{N}=1000$, among them job satisfaction level of employees situation. 
However the ratio among them is .074 individually. It provided the basic information about the selected variable in job satisfaction involved in employees effects on the basis of employees performance and skills, including the valid (no missing) sample size (n), mean, standard deviation, and standard error, which is based on $\mathrm{N}=1000$ no missing observations according to the result non-work influence. Therefore test result shows the significant.

According to given table the decision regarding the null hypothesis and the outcome of the descripted study. The obtained chi-square value exceeds the critical value, with $\mathrm{df}=4$ and $\alpha=.05$.Therefore the decision is to reject the null hypothesis. The significant result with $x^{2}(2$, $\mathrm{n}=1000)=8.535, \mathrm{p}<.05$. The means that researcher have decided there is a significant relationship between of job performance by job satisfaction level in any organization in non-work influence. However in job satisfaction with minimum expected is 93.10 regarding $\mathrm{df}=4$.

\subsection{One way ANOVA of High Job Performance}

Table 22. Table of ANOVA of high performance

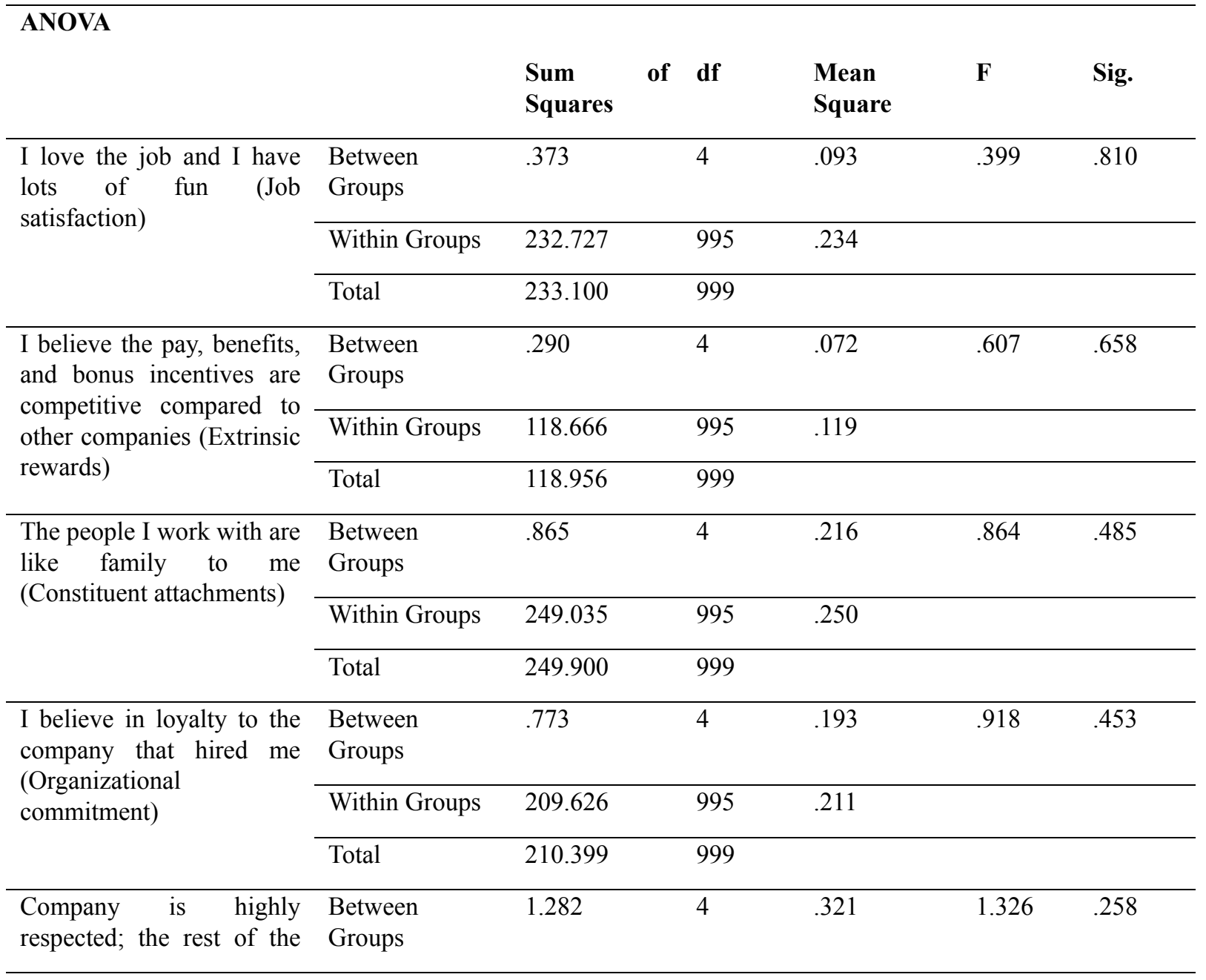




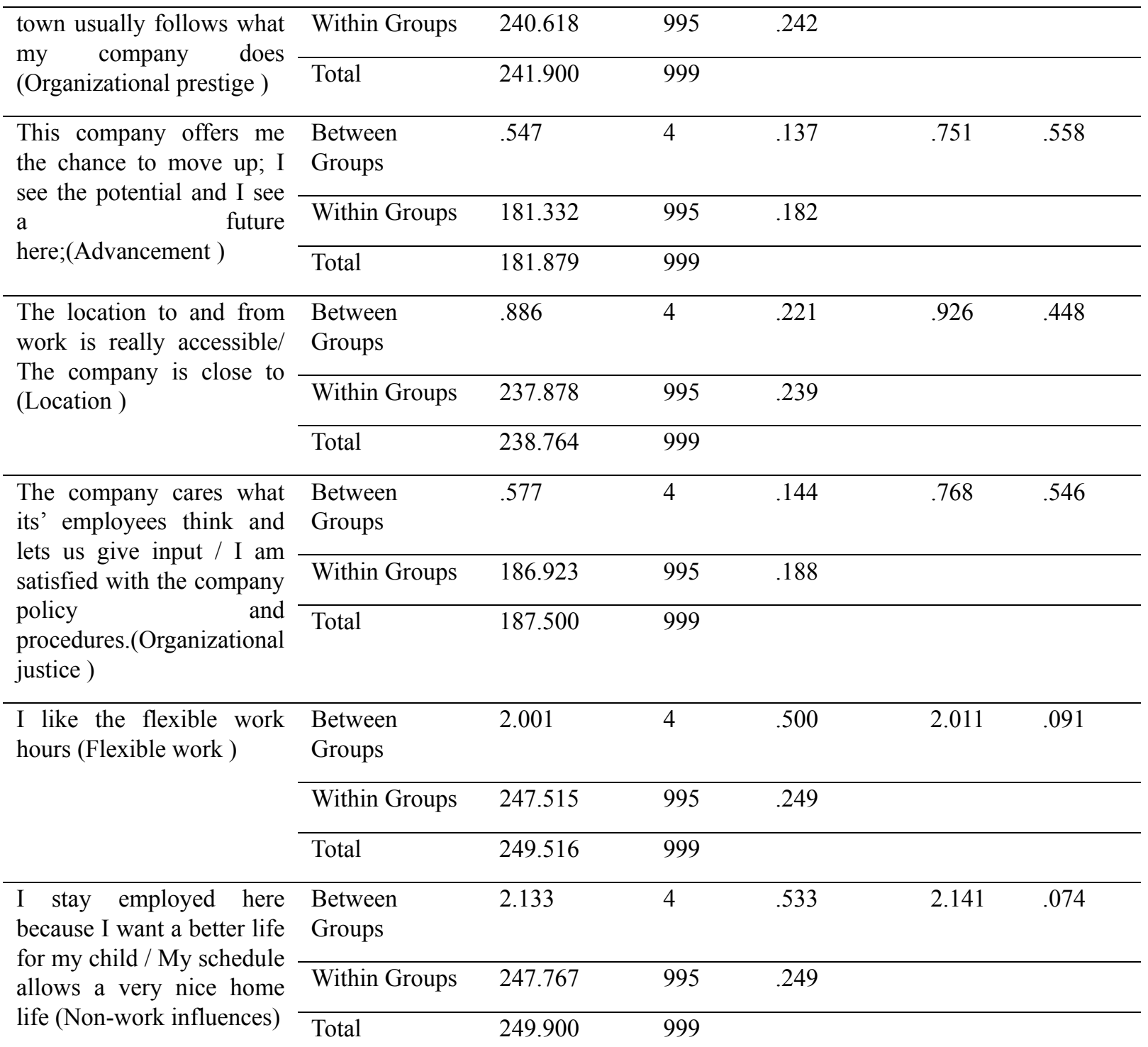

\subsubsection{Interpretation of High Performance ANOVA}

In the obtained figure result have been distributed in between and within group of individuals. The descripted $\mathrm{F}=.399$ with .810 significant figure. indicates that numerator of the $\mathrm{F}$ ratio is substantially bigger than the numerator where MS of low performance of employees is greater in between groups as comparatively MS of within groups, $\mathrm{F}$ factor .234, >.093.F values which obtain from the job performance is $65 \%$ higher from the numerator, same as like in job satisfaction, extrinsic rewards, constituent attachment, organization commitment, investment, advancement, location, organization justices, except the results of Organization prestige, and non-work influence, lack of alternatives. $F$ value obtained indicate that difference between the job performances regarding different level of parameters. Finally, researcher make statistically decision. The $\mathrm{F}$ value obtained, $\mathrm{F}=.399$, is in the critical region. It's very unlikely $(p<.05)$ that researcher have obtained a value is larger if $\mathrm{H}_{\mathrm{o}}$ is true. Therefore, researcher reject $\mathrm{H}_{\mathrm{o}}$ and conclude that there is a significant treatment effects.

However, the result of job satisfaction, extrinsic rewards, constituent attachment, organization 
commitment, organization prestige, investment, advancement, location, organization justices, non-work influence and lack of alternatives have shown that positive results, unlikely $(\mathrm{p}<.05)$ all above parameter which have finally analyses by researcher and obtained there values is larger if Ho is true. Therefore, researcher reject Ho and conclude that there is a significant treatment effects.

\subsection{Cronbach's Alpha Reliability Statistics in Low Performance}

Table 23. Case processing summary of Cronbach's Alpha

\section{Case Processing Summary}

\begin{tabular}{llll}
\hline & & $\mathbf{N}$ & $\%$ \\
\hline Cases & Valid & 1000 & 100.0 \\
& Excluded $^{\mathrm{a}}$ & 0 & 0 \\
& Total & 1000 & 100.0
\end{tabular}

a. Listwise deletion based on all variables in the procedure.

Table 24. Reliability statistics of low performance

\section{Reliability Statistics}

Cronbach's Alpha $\mathrm{N}$ of Items

\subsection{Ranking of Lack of Alternatives}

Table 25. Ranking of lock of alternatives

\begin{tabular}{|c|c|c|c|c|c|c|c|}
\hline \multicolumn{2}{|c|}{ Cross tab of Question 12} & \multicolumn{6}{|l|}{ Ranking } \\
\hline \multirow{5}{*}{$\begin{array}{l}\text { Lack of } \\
\text { alternative }\end{array}$} & Remarks & Outstanding & $\begin{array}{l}\text { High } \\
\text { successful }\end{array}$ & Successful & Marginal & $\begin{array}{l}\text { Need } \\
\text { Improvement }\end{array}$ & Total \\
\hline & No & 87 & 100 & 89 & 75 & 101 & 452 \\
\hline & & $19.2 \%$ & $22.1 \%$ & $19.7 \%$ & $16.6 \%$ & $22.3 \%$ & $100.0 \%$ \\
\hline & Yes & 126 & 108 & 101 & 116 & 97 & 548 \\
\hline & & $23.0 \%$ & $19.7 \%$ & $18.4 \%$ & $21.2 \%$ & $17.7 \%$ & $100.0 \%$ \\
\hline
\end{tabular}

In dependent variable lack of alternatives of employees have shown the outstanding result $19.2 \%$ out of 452 participants individually. $22.1 \%$ in high successful with 100 out of 452 , which is comparatively more than $2.9 \%$ as comparatively outstanding results in remark of "No". However the result shows the high successful rate in case of "No" and in case of "Yes" 


\section{Macrothink}

International Journal of Learning and Development

ISSN 2164-4063 2018, Vol. 8, No. 1

126 outstanding participant have accepted the level of performance with all depended variable but in same as above in high successful is 108 with $19.7 \%$, its $2.3 \%$ more as comparatively outstanding result individually outstanding to high successful. This is more than $2.3 \%$ less in high successful. In marginal and need improvement $5.7 \%$ high, in case of "Yes" and like 3.5\% less than from marginal to need improvement. The retention of high performance based location of employee in dependent variables from which location effects is only 39 out of 1000 , and $23.0 \%$ out of 548 participants. Therefore the result shows the high performance dependent variable of lack of alternatives of employees.

\subsubsection{Graphically View Lack of Alternatives}

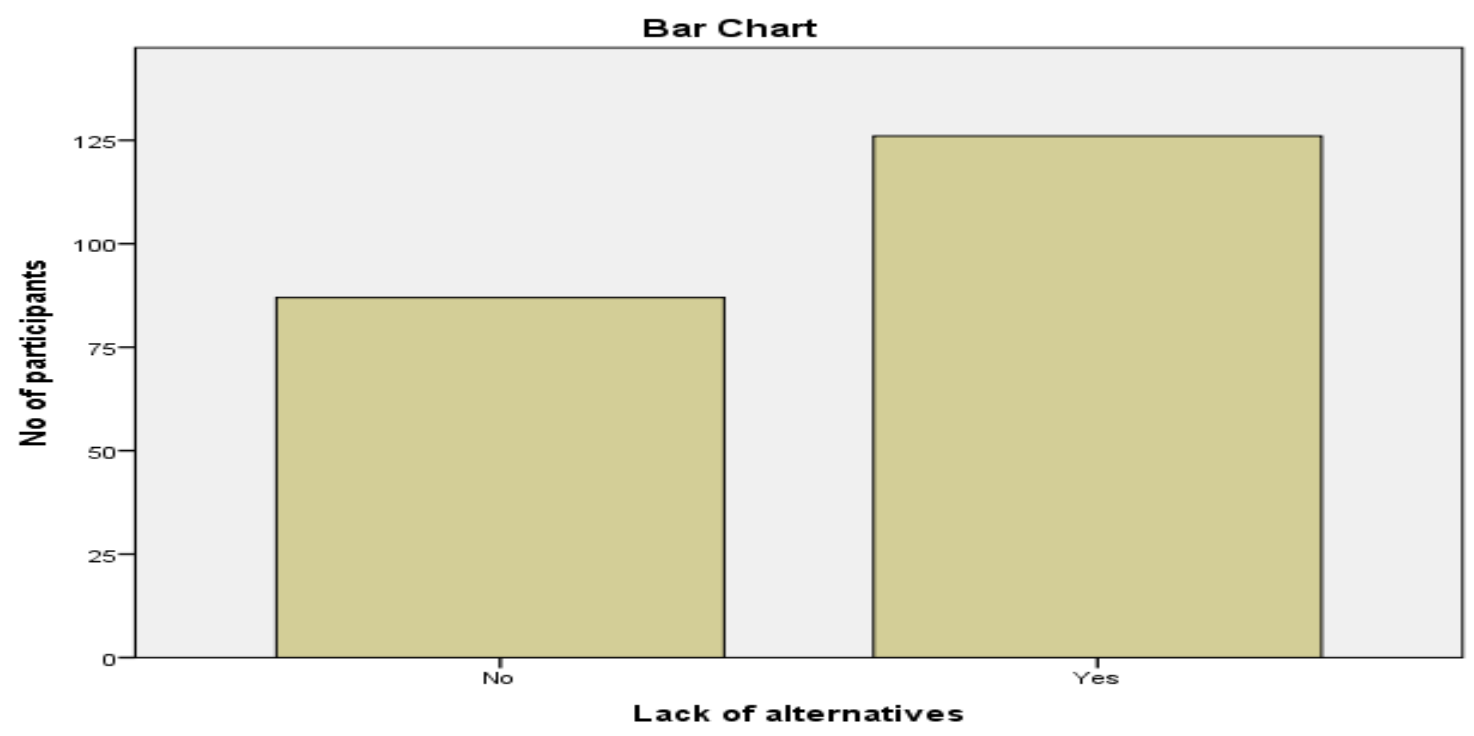

Figure 11. Lack of alternatives

In the bar chart the number of participants variation is 35 to 174 , shows the high performance in extrinsic reward and overall 184 and 174 out of $862,20.2 \%$ high performance. It shows the significant change in job performance by extrinsic reward. 


\subsubsection{Chi-Square of Lack of Alternatives}

Table 26. Chi-Square of lack of alternatives

\begin{tabular}{lccc}
\hline Chi-Square Tests & & \\
\hline & Value & df & Asymp. Sig. (2-sided) \\
\hline Pearson Chi-Square & $7.946^{\text {a }}$ & 4 & .094 \\
\hline Likelihood Ratio & 7.968 & 4 & .093 \\
\hline Linear-by-Linear Association & 1.162 & 1 & .281 \\
\hline N of Valid Cases & 1000 & & \\
\hline
\end{tabular}

a. 0 cells $(0.0 \%)$ have expected count less than 5 . The minimum expected count is 85.88 .

Table 26 indicate there is significant difference $(\mathrm{P}=.001)$ between job satisfaction of employees in high performance individually with 1000 number of participants in lack of alternatives. The valid $\mathrm{N}=1000$, among them job satisfaction level of employees situation. However the ratio among them is .094 individually. It provided the basic information about the selected variable in job satisfaction involved in employees effects on the basis of employees performance and skills in lack of alternatives, including the valid (no missing) sample size (n), mean, standard deviation, and standard error, which is based on $\mathrm{N}=1000$ no missing observations according to the result. Therefore test result shows the significant.

According to given table the decision regarding the null hypothesis and the outcome of the descripted study. The obtained chi-square value exceeds the critical value, with $\mathrm{df}=4$ and $\alpha=.05$. Therefore the decision is to reject the null hypothesis. The significant result with $x^{2}(2$, $\mathrm{n}=1000)=7.946, \mathrm{p}<.05$. The means that researcher have decided there is a significant relationship between of job performance by job satisfaction level in any organization lack of alternatives. However in job satisfaction with minimum expected is 85.58 regarding $\mathrm{df}=4$.

\subsection{Ranking of Investment}

Table 27. Ranking of investment

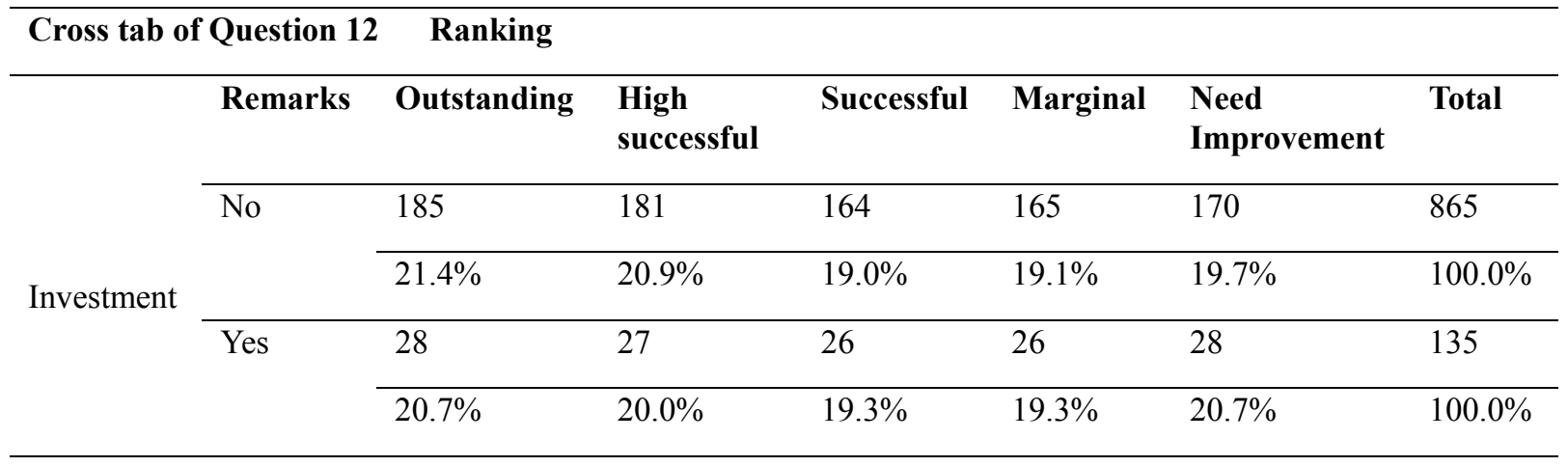




\section{N Macrothink}

International Journal of Learning and Development

ISSN 2164-4063 2018, Vol. 8, No. 1

In dependent variable investment opportunities of employees in case of low performance is directly effects on the performance of employees. It shows the outstanding result $21.4 \%$ out of 865 participants individually. $20.9 \%$ in high successful with 181 out of 865 , which is comparatively more than $.5 \%$ as comparatively outstanding results in remark of "No". However the result shows the high successful rate in case of "No" and in case of "Yes" 28 outstanding participant have accepted the level of performance with all depended variable but in same as above in high successful is 27 with $20.2 \%$, its $0.7 \%$ more as comparatively outstanding result individually. This is more than $0.7 \%$ less in high successful. In marginal and need improvement $0.6 \%$ high, in case of "Yes" and like $1.4 \%$ more from marginal to need improvement. The retention of high performance based location of employee in dependent variables from which location effects is only 157 out of 1000 , and $20.0 \%$ out of 135 participants. Therefore the result shows the high performance dependent variable of investment of employees.

\subsubsection{Graphically View of Investment}

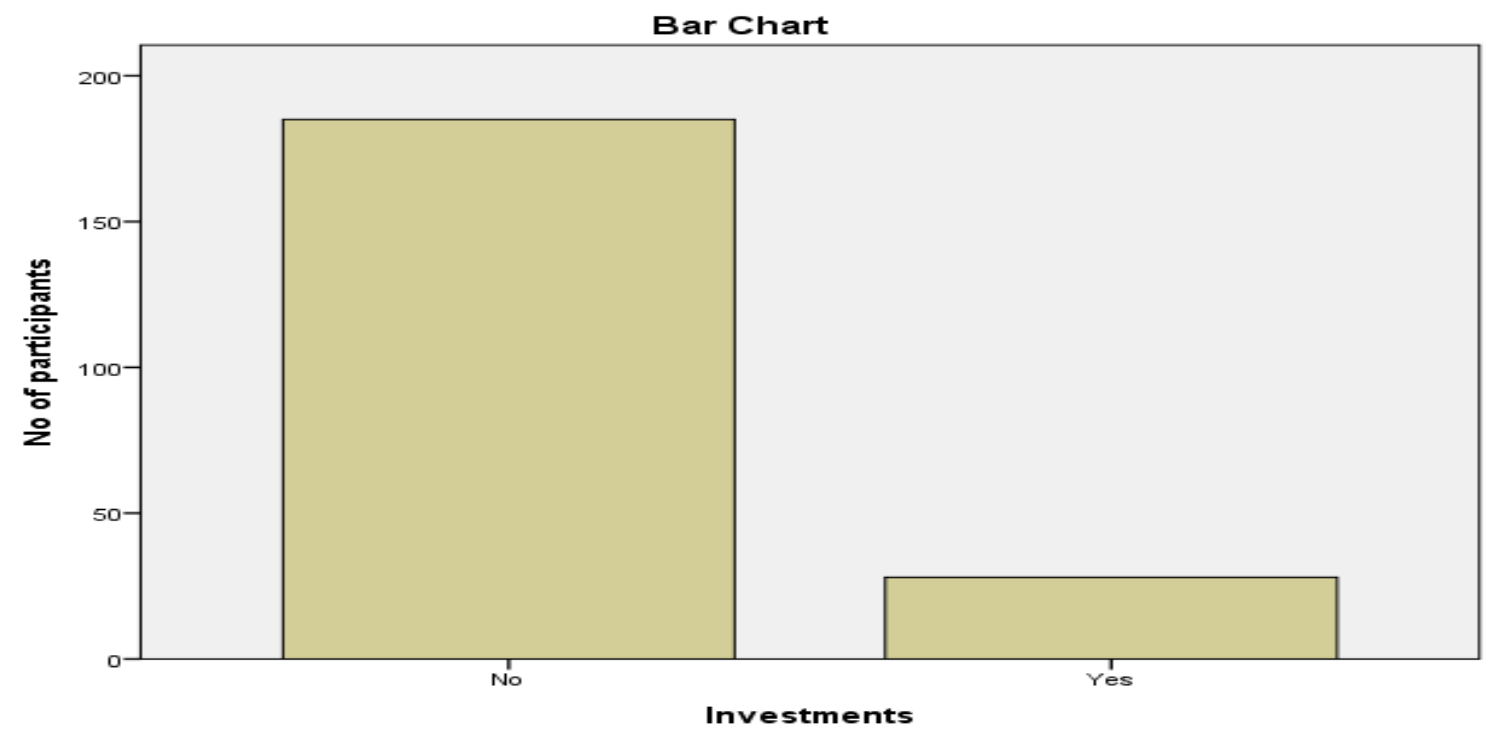

Figure 12. Investment

In the bar chart the number of participants variation is 185 to 28 , shows the high performance in extrinsic reward and overall 185 and 28 out of $135,0.15 \%$ high performance. It shows the significant change in job performance by investment. 


\subsubsection{Chi-Square of Investment}

Table 28. Chi-Square of Investment

\section{Chi-Square Tests}

\begin{tabular}{llll}
\hline & Value & df & Asymp. Sig. (2-sided) \\
\hline Pearson Chi-Square & $.148^{\mathrm{a}}$ & 4 & .997 \\
\hline Likelihood Ratio & .148 & 4 & .997 \\
\hline Linear-by-Linear Association & .120 & 1 & .729 \\
\hline N of Valid Cases & 1000 & & \\
\hline
\end{tabular}

a. 0 cells $(0.0 \%)$ have expected count less than 5 . The minimum expected count is 25.65 .

Table 28 indicate there is significant difference $(\mathrm{P}=.001)$ between job satisfaction of employees in high performance individually with 1000 number of participants in investment. The valid $\mathrm{N}=1000$, among them job satisfaction level of employees situation. However the ratio among them is .997 individually. It provided the basic information about the selected variable in job satisfaction involved in employees effects on the basis of employees performance and skills in investment, including the valid (no missing) sample size (n), mean, standard deviation, and standard error, which is based on $\mathrm{N}=1000$ no missing observations according to the result. Therefore test result shows the significant.

According to given table the decision regarding the null hypothesis and the outcome of the descripted study. The obtained chi-square value exceeds the critical value, with $\mathrm{df}=4$ and $\alpha=.05$.Therefore the decision is to reject the null hypothesis. The significant result with $x^{2}(2$, $\mathrm{n}=1000)=.148, \mathrm{p}<.05$. The means that researcher have decided there is a significant relationship between of job performance by in investment and job satisfaction level in any organization. However in job satisfaction with minimum expected is 25.65 regarding $\mathrm{df}=4$.

\subsection{ANOVA of Low Performance}

Table 29. Table of ANOVA of low performance

\begin{tabular}{|c|c|c|c|c|c|c|}
\hline \multicolumn{7}{|l|}{ ANOVA } \\
\hline & & $\begin{array}{l}\text { Sum of } \\
\text { Squares }\end{array}$ & & $\begin{array}{l}\text { Mean } \\
\text { Square }\end{array}$ & $\mathbf{F}$ & Sig. \\
\hline \multirow{3}{*}{$\begin{array}{l}\text { I can't find another job; I received no other job } \\
\text { offers while looking for work (Lack of } \\
\text { alternatives) low performance }\end{array}$} & $\begin{array}{l}\text { Between } \\
\text { Groups }\end{array}$ & 1.968 & 4 & .492 & 1.992 & .094 \\
\hline & $\begin{array}{l}\text { Within } \\
\text { Groups }\end{array}$ & 245.728 & 995 & .247 & & \\
\hline & Total & 247.696 & 999 & & & \\
\hline
\end{tabular}




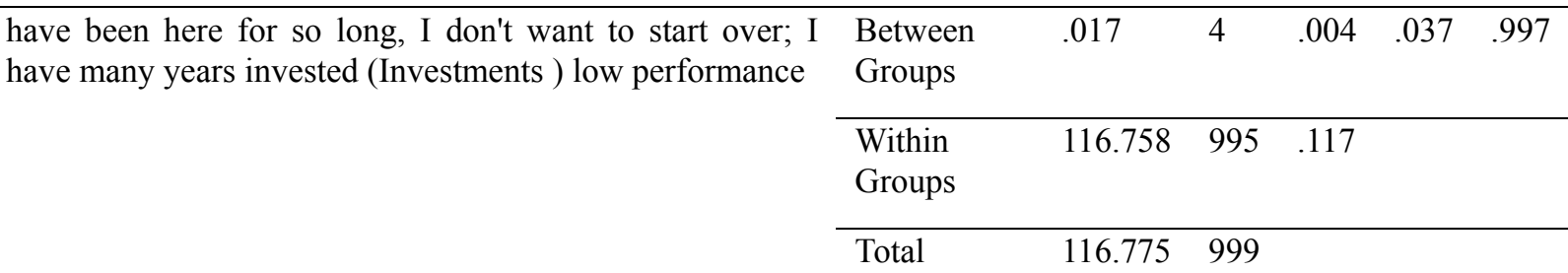

\subsubsection{Interpretation of Low Performance ANOVA}

In the obtained figure result have been distributed in between and within group of individuals. The descripted $\mathrm{F}=1.992$ with .094 significant figure. indicates that numerator of the $\mathrm{F}$ ratio is substantially bigger than the numerator where MS of low performance of employees is greater in between groups as comparatively MS of within groups, F factor $.492>.247$, F values which obtain from the low job performance is $50.20 \%$ higher from the denominator, the $\mathrm{F}$ value obtained indicate that difference between the job performance regarding different level of parameters. Finally, researcher make statistically decision. The F value obtained, $\mathrm{F}=.1 .92$, is in the critical region. It's very unlikely $(\mathrm{p}<.05)$ that researcher have obtained a value is larger if $\mathrm{H}_{\mathrm{o}}$ is true. Therefore, researcher reject $\mathrm{H}_{\mathrm{o}}$ and conclude that there is a significant treatment effects.

However, the result of investment, unlikely $(\mathrm{p}<.05)$ all above parameter which have finally analyses by researcher and obtained there values is larger if $\mathrm{H}_{\mathrm{o}}$ is true. Therefore, researcher reject $\mathrm{H}_{\mathrm{o}}$ and conclude that there is a significant treatment effects.

\subsection{Hypothesis $2^{\text {nd }}$}

\subsubsection{Ranking of Participant in Job Level by Managerial, Supervision and Professionally}

The above tables indicate the hourly employees are expected to cite transactional retention factors (i.e. Extrinsic rewards, flexible work arrangements) at a higher rate than managerial and professional employees. Managerial and professional employees are expected to cite relational factors (i.e., advancement opportunities, constituent attachments, job satisfaction, organizational commitment, organizational justice, and organizational prestige) at a higher rate than hourly employees by individually. There is significant difference $(\mathrm{P}=.001)$ between hourly employees and their retention factors with 1000 number of participants. In which job satisfaction Pearson chi-square .423 with minimum expected value is 82.14 , with $\mathrm{N}=1000$ valid cases. The remarks of job satisfaction have distributed in marginal, supervision, professional and hourly with $\mathrm{N}=370$ and $\mathrm{N}=630$. Marginal value $26.9 \%$ and there is no effects on hourly rate of remarks against of "Yes" reply, 25.9\% and in hourly it shows $27.9 \%$, which is $2 \%$ as comparatively increase by hourly rate of remarks in job satisfaction.

The valid $\mathrm{N}=1000$, among them job satisfaction level of employees situation. However the ratio among them is .809 individually. It provided the basic information about the selected variable in job satisfaction involved in employees effects on the basis of employees performance and skills, including the valid (no missing) sample size (n), mean, standard deviation, and standard error, which is based on $\mathrm{N}=100$ no missing observations according to 


\section{Ml Macrothink}

the result. Therefore test result shows the significant.

According to given table the decision regarding the null hypothesis and the outcome of the descripted study. The obtained chi-square value exceeds the critical value, with $\mathrm{df}=4$ and $\alpha=.05$. Therefore the decision is to reject the null hypothesis. The significant result with $x^{2}(3$, $\mathrm{n}=1000)=.423, \mathrm{p}<.05$. The means that researcher have decided there is a significant relationship between of job performance by job satisfaction level in any organization. However in job satisfaction with minimum expected is 82.14 regarding $\mathrm{df}=4$.

In which extrinsic rewards Pearson chi-square .711 with minimum expected value is 30.64 , with $\mathrm{N}=1000$ valid cases. The remarks of extrinsic rewards have distributed in marginal, supervision, professional and hourly with $\mathrm{N}=138$ and $\mathrm{N}=862$. Marginal value $24.6 \%$ and there is $25.4 \%$ which is $0.2 \%$ as comparatively less from marginal result on hourly rate of remarks against of "Yes" reply, 26.2\% and in hourly it shows $27.6 \%$, which is $1 \%$ as comparatively increase by hourly rate of remarks in extrinsic rewards.

According to given table the decision regarding the null hypothesis and the outcome of the descripted study. The obtained chi-square value exceeds the critical value, with $\mathrm{df}=4$ and $\alpha=.05$.Therefore the decision is to reject the null hypothesis. The significant result with $x^{2}(3$, $\mathrm{n}=1000)=.711, \mathrm{p}<.05$. The means that researcher have decided there is a significant relationship between of job performance by job satisfaction level in any organization. However in extrinsic rewards with minimum expected is 30.64 regarding $\mathrm{df}=4$.

\subsubsection{Ranking Tables of Job Level}

Table 28. Ranking of participant in different job level

\begin{tabular}{|c|c|c|c|c|}
\hline \multicolumn{5}{|l|}{ Job Satisfaction } \\
\hline Pearson Chi-Square & $.423^{\mathrm{a}}$ & 3 & .935 & \\
\hline Likelihood Ratio & .424 & 3 & .935 & \\
\hline $\begin{array}{l}\text { Linear-by-Linear } \\
\text { Association }\end{array}$ & .234 & 1 & .629 & \\
\hline $\mathrm{N}$ of Valid Cases & 1000 & & & The minimum expected value is 82.14 \\
\hline \multicolumn{5}{|l|}{ Extrinsic rewards } \\
\hline Pearson Chi-Square & $.711^{\mathrm{a}}$ & 3 & .871 & \\
\hline Likelihood Ratio & .710 & 3 & .871 & \\
\hline $\begin{array}{l}\text { Linear-by-Linear } \\
\text { Association }\end{array}$ & .010 & 1 & .919 & \\
\hline $\mathrm{N}$ of Valid Cases & 1000 & & & The minimum expected value is 30.64 \\
\hline \multicolumn{5}{|l|}{$\begin{array}{l}\text { Constituent } \\
\text { attachments }\end{array}$} \\
\hline Pearson Chi-Square & $3.604^{\mathrm{a}}$ & 3 & .308 & \\
\hline
\end{tabular}




\section{Macrothink}

International Journal of Learning and Development

ISSN 2164-4063

2018, Vol. 8, No. 1

\begin{tabular}{|c|c|c|c|c|}
\hline Likelihood Ratio & 3.606 & 3 & .307 & \\
\hline $\begin{array}{l}\text { Linear-by-Linear } \\
\text { Association }\end{array}$ & .612 & 1 & .434 & \\
\hline $\mathrm{N}$ of Valid Cases & 1000 & & & The minimum expected value is 108.84 \\
\hline \multicolumn{5}{|l|}{$\begin{array}{l}\text { Organizational } \\
\text { commitment }\end{array}$} \\
\hline Pearson Chi-Square & $2.445^{\mathrm{a}}$ & 3 & .485 & \\
\hline Likelihood Ratio & 2.408 & 3 & .492 & \\
\hline $\begin{array}{l}\text { Linear-by-Linear } \\
\text { Association }\end{array}$ & .505 & 1 & .477 & \\
\hline $\mathrm{N}$ of Valid Cases & 1000 & & & The minimum expected value is 66.82 \\
\hline \multicolumn{5}{|c|}{ Organizational prestige } \\
\hline Pearson Chi-Square & $1.006^{\mathrm{a}}$ & 3 & .800 & \\
\hline Likelihood Ratio & 1.006 & 3 & .800 & \\
\hline $\begin{array}{l}\text { Linear-by-Linear } \\
\text { Association }\end{array}$ & .985 & 1 & .321 & \\
\hline $\mathrm{N}$ of Valid Cases & 1000 & & & The minimum expected value is 91.06 \\
\hline \multicolumn{5}{|l|}{ Advancement } \\
\hline Pearson Chi-Square & $3.072^{\mathrm{a}}$ & 3 & .381 & \\
\hline Likelihood Ratio & 3.032 & 3 & .387 & \\
\hline $\begin{array}{l}\text { Linear-by-Linear } \\
\text { Association }\end{array}$ & .808 & 1 & .369 & \\
\hline $\mathrm{N}$ of Valid Cases & 1000 & & & The minimum expected value is 53.06 \\
\hline \multicolumn{5}{|l|}{ Location } \\
\hline Pearson Chi-Square & $2.239^{\mathrm{a}}$ & 3 & .524 & \\
\hline Likelihood Ratio & 2.241 & 3 & .524 & \\
\hline $\begin{array}{l}\text { Linear-by-Linear } \\
\text { Association }\end{array}$ & 1.175 & 1 & .278 & \\
\hline $\mathrm{N}$ of Valid Cases & 1000 & & & The minimum expected value is 87.47 \\
\hline \multicolumn{5}{|l|}{ Non-work influences } \\
\hline Pearson Chi-Square & $.985^{\mathrm{a}}$ & 3 & .805 & \\
\hline Likelihood Ratio & .985 & 3 & .805 & \\
\hline $\begin{array}{l}\text { Linear-by-Linear } \\
\text { Association }\end{array}$ & .452 & 1 & .502 & \\
\hline $\mathrm{N}$ of Valid Cases & 1000 & & & The minimum expected value is 108.87 \\
\hline Investment & & & & \\
\hline
\end{tabular}




\begin{tabular}{llll}
\hline Pearson Chi-Square & $2.387^{\mathrm{a}}$ & 3 & .496 \\
\hline Likelihood Ratio & 2.381 & 3 & .497 \\
\hline $\begin{array}{l}\text { Linear-by-Linear } \\
\text { Association }\end{array}$ & .035 & 1 & .852 \\
\hline N of Valid Cases & 1000 & & The minimum expected value is 29.97 \\
\hline
\end{tabular}

\subsubsection{Interpretation of Job Level}

In which constituents Pearson chi-square .3 .604 with minimum expected value is 108.84 , with $\mathrm{N}=1000$ valid cases. The remarks of extrinsic rewards have distributed in marginal, supervision, professional and hourly with $\mathrm{N}=490$ and $\mathrm{N}=510$. Marginal value $25.5 \%$ and there is $25.9 \%$ which is $0.4 \%$ as comparatively high from marginal result on hourly rate of remarks against of "Yes" reply, $26.5 \%$ and in hourly it shows $28.6 \%$, which is $1.9 \%$ as comparatively increase by hourly rate of remarks in constituent attachment.

According to given table the decision regarding the null hypothesis and the outcome of the descripted study of constituent attachment. The obtained chi-square value exceeds the critical value, with $\mathrm{df}=4$ and $\alpha=.05$.Therefore the decision is to reject the null hypothesis. The significant result with $\mathrm{x}^{2}(3, \mathrm{n}=1000)=3.604, \mathrm{p}<.05$. The means that researcher have decided there is a significant relationship between of job performance by constituent attachment level in any organization. However in extrinsic rewards with minimum expected is 108.84 regarding $\mathrm{df}=4$.

In which organization commitment Pearson chi-square 2.445 with minimum expected value is 62.4 , with $\mathrm{N}=1000$ valid cases. The remarks of extrinsic rewards have distributed in marginal, supervision, professional and hourly with $\mathrm{N}=699$ and $\mathrm{N}=301$. Marginal value $26.2 \%$ and there is $28.0 \%$ which is $1.8 \%$ as comparatively high from marginal result on hourly rate of remarks against of "Yes" reply, $25.6 \%$ and in hourly it shows $25.6 \%$, which is same as comparatively increase by hourly rate of remarks in organization commitment.

According to given table the decision regarding the null hypothesis and the outcome of the descripted study of organization commitment. The obtained chi-square value exceeds the critical value, with $\mathrm{df}=4$ and $\alpha=.05$.Therefore the decision is to reject the null hypothesis. The significant result with $\mathrm{x}^{2}(3, \mathrm{n}=1000)=2.445, \mathrm{p}<.05$. The means that researcher have decided there is a significant relationship between of job performance by constituent attachment level in any organization. However in extrinsic rewards with minimum expected is 62.4 regarding $\mathrm{df}=4$.

In which organization prestige Pearson chi-square 1.006 with minimum expected value is 91.06 , with $\mathrm{N}=1000$ valid cases. The remarks of extrinsic rewards have distributed in marginal, supervision, professional and hourly with $\mathrm{N}=590$ and $\mathrm{N}=410$. Marginal value $25.1 \%$ and there is $28.1 \%$ which is $3 \%$ as comparatively high from marginal result on hourly rate of remarks against of "Yes" reply, $27.3 \%$ and in hourly it shows $26.1 \%$, which is same as comparatively increase by hourly rate of remarks in organization prestige. 
According to given table the decision regarding the null hypothesis and the outcome of the descripted study of organization commitment. The obtained chi-square value exceeds the critical value, with $\mathrm{df}=4$ and $\alpha=.05$. Therefore the decision is to reject the null hypothesis. The significant result with $\mathrm{x}^{2}(3, \mathrm{n}=1000)=1.006, \mathrm{p}<.05$. The means that researcher have decided there is a significant relationship between of job performance by constituent attachment level in any organization. However in extrinsic rewards with minimum expected is 91.06 regarding $\mathrm{df}=4$.

In which advancement constituents Pearson chi-square 3.072 with minimum expected value is 53.6, with $\mathrm{N}=1000$ valid cases. The remarks of extrinsic rewards have distributed in marginal, supervision, professional and hourly with $\mathrm{N}=761$ and $\mathrm{N}=239$. Marginal value $26.1 \%$ and there is $28.3 \%$ which is $2.7 \%$ as comparatively high from marginal result on hourly rate of remarks against of "Yes" reply, 25.5\% and in hourly it shows $24.3 \%$, which is same as comparatively increase by hourly rate of remarks in advancement.

According to given table the decision regarding the null hypothesis and the outcome of the descripted study of organization commitment. The obtained chi-square value exceeds the critical value, with $\mathrm{df}=4$ and $\alpha=.05$.Therefore the decision is to reject the null hypothesis. The significant result with $\mathrm{x}^{2}(3, \mathrm{n}=1000)=3.072, \mathrm{p}<.05$. The means that researcher have decided there is a significant relationship between of job performance by constituent attachment level in any organization. However in extrinsic rewards with minimum expected is 53.6 regarding $\mathrm{df}=4$.

In which location Pearson chi-square 2.239 with minimum expected value is 62.4 , with $\mathrm{N}=1000$ valid cases. The remarks of extrinsic rewards have distributed in marginal, supervision, professional and hourly with $\mathrm{N}=606$ and $\mathrm{N}=394$. Marginal value $25.7 \%$ and there is $28.7 \%$ which is $3 \%$ as comparatively high from marginal result on hourly rate of remarks against of "Yes" reply, 26.4\% and in hourly it shows $25.1 \%$, which is same as comparatively increase by hourly rate of remarks in location of employees.

According to given table the decision regarding the null hypothesis and the outcome of the descripted study of organization commitment. The obtained chi-square value exceeds the critical value, with $\mathrm{df}=4$ and $\alpha=.05$. Therefore the decision is to reject the null hypothesis. The significant result with $\mathrm{x}^{2}(3, \mathrm{n}=1000)=, \mathrm{p}<.05$. The means that researcher have decided there is a significant relationship between of job performance by constituent attachment level in any organization. However in extrinsic rewards with minimum expected is 62.4 regarding $\mathrm{df}=4$.

In non-work influence Pearson chi-square .805 with minimum expected value is 108.87 , with $\mathrm{N}=1000$ valid cases. The remarks of non-work influence have distributed in marginal, supervision, professional and hourly with $\mathrm{N}=510$ and $\mathrm{N}=490$. Marginal value $25.9 \%$ and there is $28.4 \%$ which is $3.5 \%$ as comparatively low from marginal result on hourly rate of remarks against of "Yes" reply, 26.1\% and in hourly it shows $26.1 \%$, which is same as comparatively increase by hourly rate of remarks in non-work influence.

According to given table the decision regarding the null hypothesis and the outcome of the 


\section{Macrothink}

International Journal of Learning and Development

ISSN 2164-4063 2018, Vol. 8, No. 1

descripted study of non-work influence. The obtained chi-square value exceeds the critical value, with $\mathrm{df}=4$ and $\alpha=.05$. Therefore the decision is to reject the null hypothesis. The significant result with $\mathrm{x}^{2}(3, \mathrm{n}=1000)=.805, \mathrm{p}<.05$. The means that researcher have decided there is a significant relationship between of job performance by constituent attachment level in any organization. However in extrinsic rewards with minimum expected is 108.87 regarding $\mathrm{df}=4$.

In which investment Pearson chi-square 2.387 with minimum expected value is 108.87 , with $\mathrm{N}=1000$ valid cases. The remarks of extrinsic rewards have distributed in marginal, supervision, professional and hourly with $\mathrm{N}=865$ and $\mathrm{N}=135$. Marginal value $26 . .6 \%$ and there is $27.6 \%$ which is $1 . \%$ as comparatively high from marginal result on hourly rate of remarks against of "Yes" reply, 26.6\% and in hourly it shows $25.2 \%$, which is same as comparatively increase by hourly rate of remarks in investment.

According to given table the decision regarding the null hypothesis and the outcome of the descripted study of investment. The obtained chi-square value exceeds the critical value, with $\mathrm{df}=4$ and $\alpha=.05$. Therefore the decision is to reject the null hypothesis. The significant result with $\mathrm{x}^{2}(3, \mathrm{n}=1000)=2.387, \mathrm{p}<.05$. The means that researcher have decided there is a significant relationship between of job performance by constituent attachment level in any organization. However in extrinsic rewards with minimum expected is 108.87 regarding $\mathrm{df}=4$.

\subsection{Job level by Managerial, Supervisory and Professional One Way ANOVA}

Table 29. ANOVA of job level by Marginal

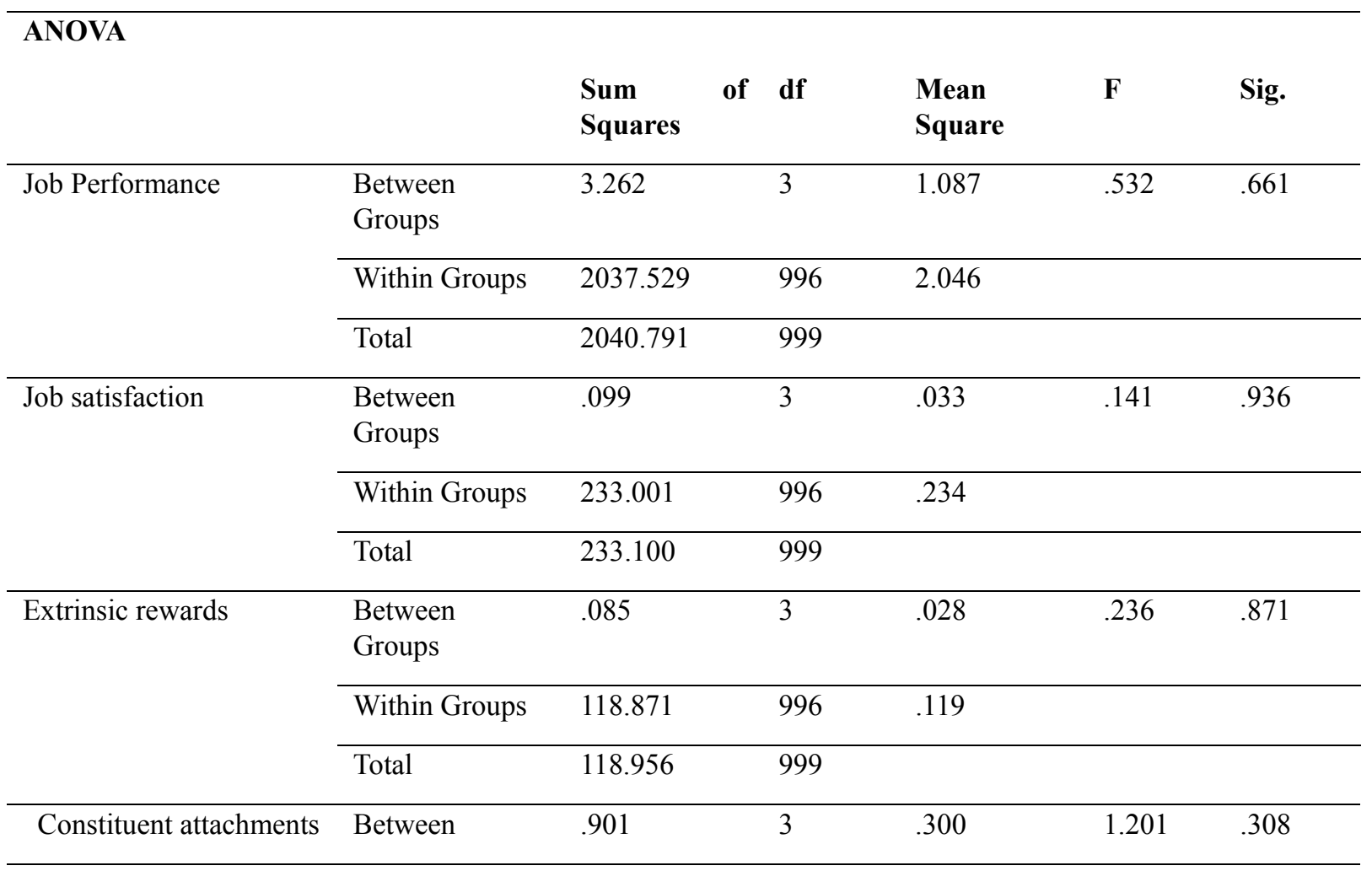




\begin{tabular}{|c|c|c|c|c|c|c|}
\hline & Groups & & & & & \\
\hline & Within Groups & 248.999 & 996 & .250 & & \\
\hline & Total & 249.900 & 999 & & & \\
\hline $\begin{array}{l}\text { Organizational } \\
\text { commitment }\end{array}$ & $\begin{array}{l}\text { Between } \\
\text { Groups }\end{array}$ & .514 & 3 & .171 & .814 & .486 \\
\hline & Within Groups & 209.885 & 996 & .211 & & \\
\hline & Total & 210.399 & 999 & & & \\
\hline Organizational prestige & $\begin{array}{l}\text { Between } \\
\text { Groups }\end{array}$ & .243 & 3 & .081 & .334 & .801 \\
\hline & Within Groups & 241.657 & 996 & .243 & & \\
\hline & Total & 241.900 & 999 & & & \\
\hline Investments & $\begin{array}{l}\text { Between } \\
\text { Groups }\end{array}$ & .279 & 3 & .093 & .795 & .497 \\
\hline & Within Groups & 116.496 & 996 & .117 & & \\
\hline & Total & 116.775 & 999 & & & \\
\hline Advancement & $\begin{array}{l}\text { Between } \\
\text { Groups }\end{array}$ & .559 & 3 & .186 & 1.023 & .382 \\
\hline & Within Groups & 181.320 & 996 & .182 & & \\
\hline & Total & 181.879 & 999 & & & \\
\hline (Location ) & $\begin{array}{l}\text { Between } \\
\text { Groups }\end{array}$ & .535 & 3 & .178 & .745 & .525 \\
\hline & Within Groups & 238.229 & 996 & .239 & & \\
\hline & Total & 238.764 & 999 & & & \\
\hline Organizational justice ) & $\begin{array}{l}\text { Between } \\
\text { Groups }\end{array}$ & .005 & 3 & .002 & .010 & .999 \\
\hline & Within Groups & 187.495 & 996 & .188 & & \\
\hline & Total & 187.500 & 999 & & & \\
\hline (Non-work influences) & $\begin{array}{l}\text { Between } \\
\text { Groups }\end{array}$ & .246 & 3 & .082 & .327 & .806 \\
\hline & Within Groups & 249.654 & 996 & .251 & & \\
\hline & Total & 249.900 & 999 & & & \\
\hline (Lack of alternatives & $\begin{array}{l}\text { Between } \\
\text { Groups }\end{array}$ & .610 & 3 & .203 & .820 & .483 \\
\hline & Within Groups & 247.086 & 996 & .248 & & \\
\hline & Total & 247.696 & 999 & & & \\
\hline
\end{tabular}




\section{Al Macrothink}

International Journal of Learning and Development

ISSN 2164-4063 2018, Vol. 8, No. 1

\subsubsection{Interpretation of ANOVA}

In the obtained figure result have been distributed in between and within group of individuals. The descripted $\mathrm{F}=.532$ with .661 significant figure. indicates that numerator of the $\mathrm{F}$ ratio is substantially bigger than the numerator where MS of low performance of employees is greater in between groups as comparatively MS of within groups, F factor .532>.141, F values which obtain from the job performance is $62 \%$ higher from the denominator, the $\mathrm{F}$ value obtained indicate that difference between the job performance regarding different level of parameters. Finally, researcher make statistically decision. The $\mathrm{F}$ value obtained, $\mathrm{F}=.532$, is in the critical region. It's very unlikely $(p<.05)$ that researcher have obtained a value is larger if $\mathrm{H}_{\mathrm{o}}$ is true. Therefore, researcher reject $\mathrm{H}_{\mathrm{o}}$ and conclude that there is a significant treatment effects.

However, the result of job satisfaction, extrinsic rewards, constituent attachment, organization commitment, organization prestige, investment, advancement, location, organization justices, non-work influence and lack of alternatives have shown that positive results, unlikely $(\mathrm{p}<.05)$ all above parameter which have finally analyses by researcher and obtained there values is larger if Ho is true. Therefore, researcher reject Ho and conclude that there is a significant treatment effects.

\subsection{Second Parameter of Lack of Alternatives and Flexible Work}

In which lack of alternatives Pearson chi-square 2.464 with minimum expected value is 100.04 , with $\mathrm{N}=1000$ valid cases. The remarks of extrinsic rewards have distributed in marginal, supervision, professional and hourly with $\mathrm{N}=452$ and $\mathrm{N}=548$. Marginal value $25.7 \%$ and there is $27.7 \%$ which is $2 \%$ as comparatively high from marginal result on hourly rate of remarks against of "Yes" reply, 26.3\% and in hourly it shows $27 \%$, which is same as comparatively increase by hourly rate of remarks in lack of alternatives.

According to given table the decision regarding the null hypothesis and the outcome of the descripted study of lack of alternatives. The obtained chi-square value exceeds the critical value, with $\mathrm{df}=4$ and $\alpha=.05$. Therefore the decision is to reject the null hypothesis. The significant result with $\mathrm{x}^{2}(3, \mathrm{n}=1000)=2.646, \mathrm{p}<.05$. The means that researcher have decided there is a significant relationship between of job performance by constituent attachment level in any organization. However in extrinsic rewards with minimum expected is 100.34 regarding $\mathrm{df}=4$.

\subsubsection{Ranking of Lack of Alternative and Flexible Work}

Table 30. Ranking of lack of alternatives and flexible work

\begin{tabular}{llll}
\hline Lack of alternatives & & & \\
\hline Pearson Chi-Square & $2.464^{\mathrm{a}}$ & 3 & .482 \\
\hline Likelihood Ratio & 2.468 & 3 & .481 \\
\hline
\end{tabular}




\begin{tabular}{|c|c|c|c|c|}
\hline Linear-by-Linear Association & .517 & 1 & .472 & \\
\hline $\mathrm{N}$ of Valid Cases & 1000 & & & 100.34 \\
\hline \multicolumn{5}{|l|}{ Flexible work } \\
\hline Pearson Chi-Square & $3.176^{\mathrm{a}}$ & 3 & .365 & \\
\hline Likelihood Ratio & 3.176 & 3 & .365 & \\
\hline Linear-by-Linear Association & 1.240 & 1 & .265 & \\
\hline $\mathrm{N}$ of Valid Cases & 1000 & & & 106.04 \\
\hline
\end{tabular}

In which flexible work Pearson chi-square 3.176 with minimum expected value is 106.04 , with $\mathrm{N}=1000$ valid cases. The remarks of extrinsic rewards have distributed in marginal, supervision, professional and hourly with $\mathrm{N}=478$ and $\mathrm{N}=522$. Marginal value $24.3 \%$ and there is $27.4 \%$ which is almost $3 \%$ as comparatively high from marginal result on hourly rate of remarks against of "Yes" reply, 27.6\% and in hourly it shows $27.2 \%$, which is same as comparatively increase by hourly rate of remarks in flexible work.

According to given table the decision regarding the null hypothesis and the outcome of the descripted study of organization commitment. The obtained chi-square value exceeds the critical value, with $\mathrm{df}=4$ and $\alpha=.05$.Therefore the decision is to reject the null hypothesis. The significant result with $\mathrm{x}^{2}(3, \mathrm{n}=1000)=3.176, \mathrm{p}<.05$. The means that researcher have decided there is a significant relationship between of job performance by constituent attachment level in any organization. However in extrinsic rewards with minimum expected is 106.04 regarding $\mathrm{df}=4$.

4.20 Job Level by Hourly One Way ANOVA

Table 31. ANOVA by hourly

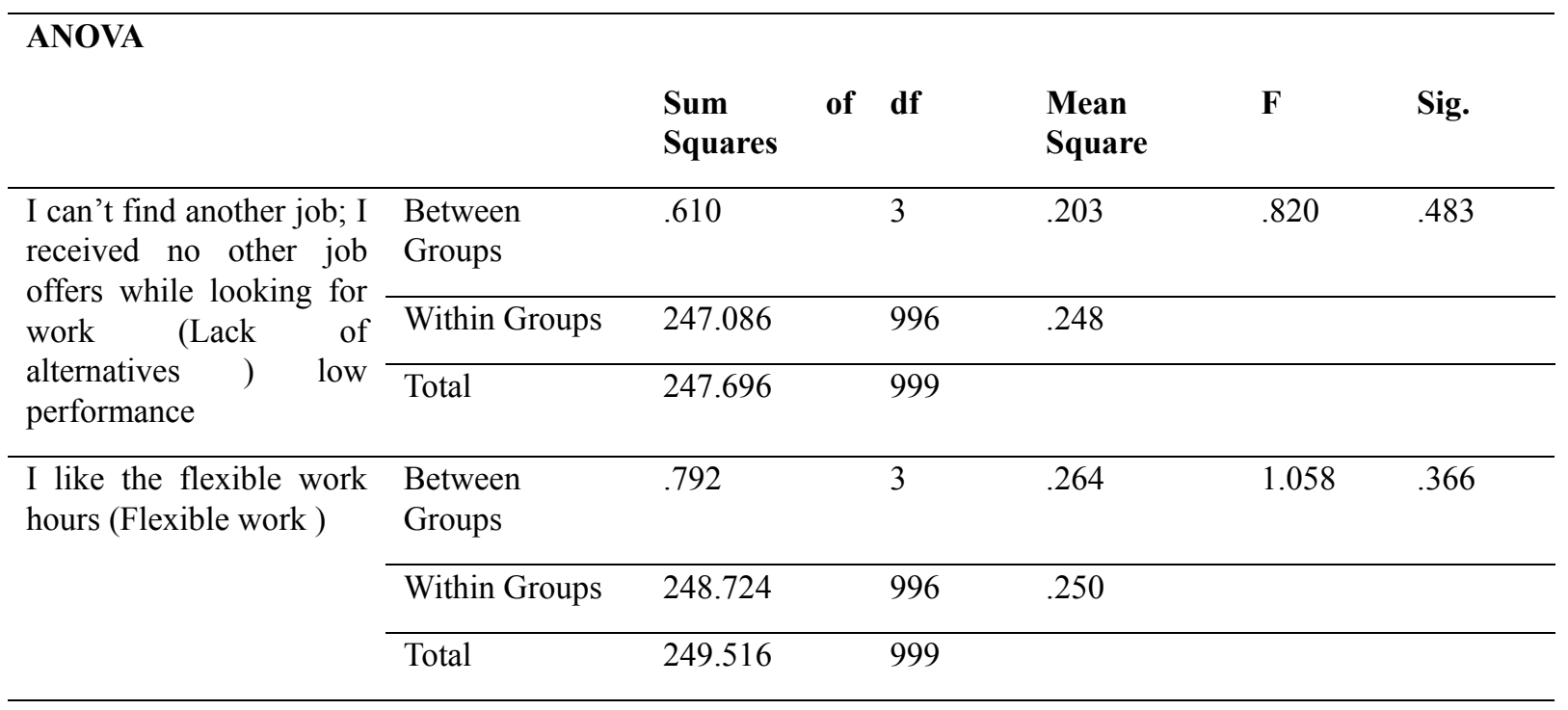




\subsection{Interpretation of ANOVA}

In the obtained figure result have been distributed in between and within group of individuals. The descripted $\mathrm{F}=.820$ with .483 significant figure. indicates that numerator of the $\mathrm{F}$ ratio is substantially bigger as comparatively from between group and the numerator where MS of hourly job level of employees is greater in between groups as comparatively MS of within groups, $\mathrm{F}$ factor $247.86>.610, \mathrm{~F}$ values which obtain from the hourly job level is $68 \%$ higher from the denominator, but their significant figure is shows .483 which less than .05 , the $\mathrm{F}$ value obtained indicate that difference between the job performance regarding different level of parameters. Finally, researcher make statistically decision. The F value obtained, $F=0.820$, is in the critical region. It's very unlikely $(\mathrm{p}<.05)$ that researcher have obtained a value is larger if Ho is true. Therefore, researcher reject Ho and conclude that there is a significant treatment effects.

However, the result of lack of alternatives and flexible work have shown that positive results, unlikely $(\mathrm{p}<.05)$ all above parameter which have finally analyses by researcher and obtained there values is larger if Ho is true. Therefore, researcher reject Ho and conclude that there is a significant treatment effects.

\section{Recommendation and Conclusion}

Basically to know the job performance and evaluate the role of employees on job performance in industrial sector of Punjab and find out job performance in different level of job level. The research inaugurated with a brief circumstantial to the study, announcement of the badly-behaved, objectives of the training, research interrogations and its significance and re-joining the detailed questions acknowledged for the calculation.

The conclusions of this examination will have wide suggestions for employee routine and effective retention approaches industrial sector of Punjab must adopt to retain its auspicious staff. Preservation is a central concept that has been getting considerable helpfulness from academicians, academics and committed with supervisors. In its essence, retention embraces important foundations such as the need for relentless search and choice of approaches, goal-directed behaviors, bootees and recognition, performance-satisfaction along with industrial sector of Punjab. The snowballing attention paid towards preservation is acceptable because of several reasons of retention of job performance. Reinvigorated employees come out with new ways of doing possessions that improve the attractiveness of administrations.

Positive officialdoms comprehend by having an current operative maintenance plan will help them sustain their control and growth in the fair, increased taxes for the administration prominent to increased income. Good administrations in industrial sector of Punjab make operative retention a core component of their capacity administration strategy and administrative enlargement process very encouraging industrial sector of Punjab. Those that fail to make underling retention a priority are at risk of losing their top talented individuals to the opposition industrial sector of Punjab.

Additionally, supplementary good-looking market for job pursuer's industrial sector of Punjab means that the transferring costs of seeking new employment are no longer a 
substantial factor in deciding whether or not to agreement an association industrial sector of Punjab.

The following were key issues outlined by majority of the respondents:

- With above researcher questions more $85.58 \%$ job performance change due to high retention factors, where the High performers will cite retention factors that indicate low desirability of movement (i.e., advancement opportunities, constituent attachments, extrinsic rewards, flexible work arrangements, job satisfaction, location, non-work influences, organizational commitment, organizational justice, organizational prestige) at a higher rate than low performers. And also the Low performers will cite factors that reflect low ease of movement (i.e., investments, lack of alternatives) at a higher rate than high performers of employees.

- Regarding few stated situation $13.65 \%$ retention factors not directly effects on job performance but the significant result shows in overall more than $90 \%$ result in job performance.

- Additionally all respondents from both senior and junior staff level designated that if the work is not respected by the superintendent order and different terms conditions of the employee feels de-motivated and misplaces interest in the job performance.

- Mainstream of workforces disclosed that remuneration has been their maximum experiment working with Punjab industries.

- In the Punjab industries the majority of plaintiffs revealed that they would classify the idea of making workforces realize that they are the most valuable asset of the association as the best preparation in employee maintenance approaches.

- Personnel in the subordinate staff level released that it is unbelievably imperative to include team adherents in the decision making processes, especially when pronouncements will affect an personality's subdivision or work lineup.

\subsection{Conclusions}

Workforce's famine to be predictable for a job sound by two retention factors. Plunders and recognition respond to this requirement by authorizing show and motivating workforces toward continuous enhancement. Pleasing and recognizing people for presentation not only move the individual being predictable, but others in the institute as glowing. Also it indicate there is significant difference $(\mathrm{P}=.001)$ between job satisfaction of employees in high performance individually with 1000 number of participants. The valid $\mathrm{N}=1000$, among them job satisfaction level of employees situation. It provided the basic information about the selected variable in job satisfaction involved in employees effects on the basis of employees performance and skills, including the valid (no missing) sample size (n), mean, standard deviation, and standard error, which is based on $\mathrm{N}=100$ no missing observations according to the result. Therefore test result shows the significant.

Through a bootees program, the complete association can understanding the obligation to 
excellence, when the repayment system is dependable and bootees are eloquent. However, if the reward system is cracked, the opposite effect will occur. Workforces may feel that their performance is unrecognized and not valued, or that others in the association are remunerated for the wrong behaviors. Unrecognized and no valued presentation can underwrite to revenue. Acknowledgement for a job well done fills the underlings' need to receive positive, up-front feedback for their efforts in industrial sector of Punjab.

\subsection{Findings}

There are some of following finding are valuable means by job performance and different level of job that directly influence the employee retention factors in Punjab industrial sectors. Some of the specific findings in this regard are: In the area of association fit association philosophy play important role in underling maintenance. Family support and flex time culture is contemplate significant factor in operative retention. Reimbursement, reward and acknowledgement play a key role in employee's enthusiasm which leads to servant's retention in the suggestion.

1. Progress to identify the business strategies regarding job performance.

2. Identify and support control with probable for movement to the top level of management and their services.

3. Individual development in each sector of industrial sector and their corporative strategies.

4. Develop the path of job level and performance under represented areas or rules.

5. Integrate career expansion into appraisal progressions by counting negotiations on objectives and discovering barriers of the entire organization.

6. By the retention factors individual industries as well shows reputed structure of management.

7. Use management along with firstborn administrator's computer operator as a feeder to a sequence preparation of management program.

8. Contemplate a built-up programme for management trainees regarding advancement of industries and staffing. And also encourage the core value of progress.

9. Design training programmers around the capabilities needed for posts and pay development, connecting the information and assistances opening to allow management expects.

Similarly Training and career development in management also created well structure management value in competitive market with employee retention and was found important influencing factor in employee retaining in the organization. Operative profession loan aspect or elevation occasions have earth-shattering relative with employees " retention and deliberate as imperative factor in employee retention. 


\section{Macrothink}

\subsection{Recommendations}

Some of the recommendations for the management tasked to manage employees towards successful attainment of organizational goals are:

- By the job performance industrial organization needs to further improve its culture as it has the possible to retain employees, which will help it to retain its valuable assets.

- The ranking job system may be comfortable which will help administration in answering the question why teams leave them, and then work on those areas which encouragement employees to leave their association.

- Revenue rate ought be monitor and consider it significant in policy erection regarding HR factors and organization factors; it will help management in retaining their workforces.

- It is recommended that workforces want fair handling and fair evaluation regarding the HR practices, so administrations need to bring fair policy of industrial sector of Punjab and communicate it to their employees in small village.

- Acknowledgement of the workforces" inputs and outcomes need supplementary enhancements. This concept may be enhanced if organization comfortable formal recognition system i.e. documentations, employee of the year etc.

- By the job performance reward should be bestowed on merit and advancement should be on seniority and merit both, which help in construction and retention.

- The remuneration of employee need to be enlarged, which will not only remember the present employees but will fascinate employees of other organization as well.

- Organizations should categorize those benefits which have more encouragement on employee retention. Additionally, Organizations need to revisit their present benefits package to identify those benefits which are not useful in order to replace them.

- An exercise program may be established as a regular practice for establishment of training and retraining (refreshment courses) opportunities for their workforces. This would not only satisfy employee's growth need but also enhance employee retention.

- A psychoanalysis system may be established regarding counselling employees for their career development, which will enhance employee loyalty with the organization.

- By the performance of job employees need to recognize that they are in organization, where they are offered multi training and career development opportunities so they should avail these openings to increase their marketability.

\subsection{Research Implication}

The following are the recommendations from the research implication.

- In the employees performance provided proper feedbacks should be done with proper documentation according to industries requirement. 


\section{Macrothink}

International Journal of Learning and Development

ISSN 2164-4063 2018, Vol. 8, No. 1

- Employees should be involved in the formulation of appraisal tool in job ranking.

- Give appropriate system rewards to employees who have shown an archetypal performance.

- Employees should be appraised on the basis of the necessities of their job, their duties and responsibilities

- The assessment tool should measure the diversity function of the employees.

- Appraisal system must have a clear sense of direction in industrial system.

- The evaluation of employees must have fair and reverential management.

- Establishment of corrective mechanism is vital role of industrial system.

\section{Acknowledgements}

\section{National Natural Science Foundation of China No: 71371087}

The authors would like to thanks the editors and anonymous reviewers of the International journal of Learning and Development for reviewing the manuscript and provide valuable comments for making improvement of this paper.

\section{References}

Adams, J. (1963). Towards an understanding of inequity. Abnormal and Social Psychology, 67, 422-436. https://doi.org/10.1037/h0040968

Adams, J. S. (1965). Inequity in social exchange. In L. Berkowitz (Ed.), Advances in experimental social psychology (Vol. 2, pp. 267-299). New York: Academic Press. https://doi.org/10.1016/S0065-2601(08)60108-2

Agarwal, N. C. (1998). Reward Systems: Emerging Trends and Issues. Canadian Psychology, 39(1), 60-70. https://doi.org/10.1037/h0086795

Aliya, Ah., \& Shadab, F. (2003). The motivation to work. Journal of industrial sectors investment and organization development.

Allen, T. D. (2001). Family-Supportive Work Environments: The Role of Organizational Perceptions. Journal of Vocational Behavior. 58(3), 414-435. https://doi.org/10.1006/jvbe.2000.1774

Amar, A. D. (2004), Motivating knowledge workers to innovate: A model integrating Motivation dynamics and antecedents. European Journal of Innovation Management. https://doi.org/10.1108/14601060410534366

Edmonstone D. (1996). Performance Management: a review of general concepts and issues. Liverpool School of Management.

Griffeth, R. W., Hom, P. W., \& Gaertner, S. (2000). A meta-analysis of antecedents and correlates of worker turnover: Update, moderator tests, and research implications for the next 
millennium. Journal 2018, Vol. 8, No. 1

https://doi.org/10.1177/014920630002600305

Griffeth, R.W., Steel, R.P., Allen, D.G., \& Bryan, N. (2005). The development of a multidimensional measure of job market cognitions: The Employment Opportunity Index $\begin{array}{llll}\text { (EOI). Journal of Applied } & \text { Psychology, } & \text { 90, }\end{array}$ https://doi.org/10.1037/0021-9010.90.2.335

Griffeth, R. W. (2001). Test of a mediated performance-turnover relationship highlighting the moderating roles of visibility and reward contingency. Journal of Applied Psychology, 76, 991-1000.

Aquino, K., Griffeth, R. W., Allen, D. G., \& Hom, P. W. (1997). Integrating justice constructs into the turnover process: A test of a referent cognitions model. Academy of Management Journal, 50, 825-26. https://doi.org/10.2307/256933

Baltes, B. B., Briggs, T. E., Huff, J. W., Wright, J. A., \& Neuman, G. A. (1999) Flexible and compressed workweek schedules: A meta-analysis of their effects on work-related criteria. Journal of Applied Psychology, 84, 36-45. https://doi.org/10.1037/0021-9010.84.4.496

Branham, L. (2005). Planning to become an employer of choice. Journal of Organizational Excellence, 24, 57-68. https://doi.org/10.1002/joe.20060

Collins, C. J. (2007). The interactive effects of recruitment practices and product awareness on job seekers' employer knowledge and application behaviors. Journal of Applied Psychology, 92, 175. https://doi.org/10.1037/0021-9010.92.1.180

Delaney, J. and Huselid, M. (1996). The impact of HRM practices on perception of organizational performance. In Academy of Management Journal. 39, 949-69. https://doi.org/10.2307/256718

Deutsch, M. (1975). Equity, equality, and need: What determines which value will be used as the basis of distributive justice? Journal of Social issues, 31, 137-150. https://doi.org/10.1111/j.1540-4560.1975.tb01000.x

Dalton, D. R., \& Mesch, D. J. (1990). The impact of flexible scheduling on worker attendance and turnover. Administrative Science Quarterly, 35, 285-300. https://doi.org/10.2307/2393395

Dalton, D. R., \& Todor, W. D. (1979). Turnover turned over: An expanded and positive perspective. Academy of Management Review, 4, 325-30. https://doi.org/10.5465/AMR.1979.4289021

Kristof, A. L. (1996). Person organization fit: an integrative review of its conceptualizations, measurement, and implications. In Personnel Psychology. 49, 1-49.

Kyriakidou, O., \& Ozbilgin, M. (2004), "Individuals, organizations and careers: a relational perspective". Career Development International, 9(1), 7-11.

Hom, P. W., \& Griffeth, R.W. (1995). Worker turnover. Cincinnati, OH: South-Western. 


\section{Macrothink}

International Journal of Learning and Development

ISSN 2164-4063 2018, Vol. 8, No. 1

Marchington, M., \& Wilkinson, A. (2005). Human resource management at work: people management and development. Balor University, USA, 2005.

Sundstrom, E., DE Meuse, K. P., \& Futrell, D. (1990). Work teams: Applications and effectiveness. American Psychologist, 45(120), 133.

Steers, R. (1977). Antecedents and outcomes of organizational commitment. Administrative Science Quarterly, 22, 46-56. https://doi.org/10.2307/2391745

Strauss, A., \& Corbin, A. (1998). Basics of qualitative research: Techniques and procedures for developing grounded theory (2nd ed.). Thousand Oaks, CA: Sage

\section{Notes}

Note 1. HPWOs are organisations which take a strategic approach towards managing people, recognising that the full benefits of workforce development can only be achieved by adopting a wide array of workplace changes and human resource practices which impact on performance. See, for instance, Becker and Huselid (1998).

Note 2. WERS 2004 included a question on overskilling with over half the sample falling into this category.

\section{Copyright Disclaimer}

Copyright for this article is retained by the author(s), with first publication rights granted to the journal.

This is an open-access article distributed under the terms and conditions of the Creative Commons Attribution license (http://creativecommons.org/licenses/by/4.0/). 